\title{
Transcriptional profiling reveals barcode-like toxicogenomic responses in the zebrafish embryo Lixin Yang* ${ }^{*}$ Jules R Kemadjou*, Christian Zinsmeister*, Matthias Bauer*, Jessica Legradi ${ }^{*}$, Ferenc Müller ${ }^{*}$, Michael Pankratz ${ }^{*}$,Jens Jäkel ${ }^{\dagger \neq}$ and Uwe Strähle*
}

\begin{abstract}
Addresses: *Institute of Toxicology and Genetics, Forschungszentrum Karlsruhe, Postfach 3640, 76021 Karlsruhe, Germany. ${ }^{\dagger}$ Institute for Applied Computer Science, Forschungszentrum Karlsruhe, Postfach 3640, 76021 Karlsruhe, Germany. ${ }^{*}$ Institute for Measurement and Control Engineering, HTWK Leipzig, Postfach 3011 66, 04251 Leipzig, Germany.
\end{abstract}

Correspondence: Uwe Strähle. Email: uwe.straehle@itg.fzk.de

Published: 25 October 2007

Genome Biology 2007, 8:R227 (doi:10.1 I86/gb-2007-8-10-r227)

The electronic version of this article is the complete one and can be found online at http://genomebiology.com/2007/8/I0/R227
Received: 23 July 2007

Revised: 17 September 2007

Accepted:

(C) 2007 Yang et al; licensee BioMed Central Ltd. This is an open access article distributed under the terms of the Creative Commons Attribution License (http://creativecommons.org/licenses/by/2.0), which permits unrestricted use, distribution, and reproduction in any medium, provided the original work is properly cited

\begin{abstract}
Background: Early life stages are generally most sensitive to toxic effects. Our knowledge on the action of manmade chemicals on the developing vertebrate embryo is, however, rather limited. We addressed the toxicogenomic response of the zebrafish embryo in a systematic manner by asking whether distinct chemicals would induce specific transcriptional profiles.

Results: We exposed zebrafish embryos to a range of environmental toxicants and measured the changes in gene-expression profiles by hybridizing cDNA to an oligonucleotide microarray. Several hundred genes responded significantly to at least one of the II toxicants tested. We obtained specific expression profiles for each of the chemicals and could predict the identity of the toxicant from the expression profiles with high probability. Changes in gene expression were observed at toxicant concentrations that did not cause morphological effects. The toxicogenomic profiles were highly stage specific and we detected tissue-specific gene responses, underscoring the sensitivity of the assay system.

Conclusion: Our results show that the genome of the zebrafish embryo responds to toxicant exposure in a highly sensitive and specific manner. Our work provides proof-of-principle for the use of the zebrafish embryo as a toxicogenomic model and highlights its potential for systematic, large-scale analysis of the effects of chemicals on the developing vertebrate embryo.
\end{abstract}

\section{Background}

Organisms are open systems that are in constant exchange with their environment. As a consequence, living systems have to adapt to environmental conditions by adjusting their physiology accordingly. Chemicals from natural sources or manmade pollution can represent rather adverse environ- mental conditions with a fatal outcome if the organism fails to adapt. It is a well-established fact that xenobiotics such as dioxin or cadmium can induce changes in gene expression [13]. The responsive genes include adaptive genes that are involved in detoxification or protection against oxidative or other cellular stresses and may also comprise genes that are 
directly responsible for the fatal effects of the toxicants. The early life stages of vertebrates are generally the most susceptible to adverse chemical impact [4]. Yet we do not have a detailed picture of the transcriptional response profiles of these early life stages.

There is a high demand by regulators and industry for reliable and ethically acceptable methods to evaluate the developmental toxicity of pharmaceuticals, industrial chemicals and waste products. For example, several tens of thousands of chemicals need to be assessed within the European Union REACH (Registration, Evaluation and Authorization of Chemicals) initiative for the safety testing and risk assessment of chemicals in the next years $[5,6]$. Cheap and reliable alternative methods are needed to cope with this enormous screening effort.

Toxicogenomics is a powerful tool for studies of toxicological mechanisms and for the detection of toxicity profiles [7] as it allows the simultaneous assessment of thousands of genes. To obtain the full potential of toxicogenomics for the evaluation of developmental toxicity, however, animal systems have to be used. The zebrafish embryo is a vertebrate system with great merits for this undertaking. The zebrafish was introduced more than two decades ago as a model to study development and neurobiology [8]. In parallel, the zebrafish embryo has evolved into a model for studies of chemical impact: it permits efficient compound screens [9] and is, for example, used in a standardized assay for sewage testing in Germany, replacing traditional toxicological tests with adult fish $[10,11]$. Given the experimental advantages such as small size of the embryo, cheap maintenance, availability of a genome sequence and many mutants, the zebrafish embryo is one of the most promising vertebrate systems for studies of toxicological mechanisms and toxicogenomics [12-14]. Most assays using zebrafish, however, rely on morphological endpoints, which display little discrimination between different toxicants.

Expression profiling has just recently entered zebrafish research [15-20] and only a few toxicogenomic studies exist $[1,21,22]$. Dioxin (TCDD) impairs fin regeneration in adult zebrafish, and expression profiling revealed TCDD-induced changes in the expression of genes involved in extracellular matrix formation [1,23]. Exposure of zebrafish to arsenic leads to changes in gene expression in adult zebrafish liver very similar to those reported for mammals, suggesting damage to protein and DNA and increased oxidative stress in the livers of arsenic-treated animals [22]. In another pilot study, zebrafish embryos were exposed to the reference compound 3,4-dichloroaniline and seven genes were significantly regulated [21].

Despite these advances, however, it is not known whether there are different responses to different toxicants and at different developmental stages. Would different toxic chemicals induce different genomic profiles, which might even be diagnostic for particular toxicants, or does the genome of the embryo respond in a general stress response. Would the sensitivity of whole-embryo exposure experiments be high enough to detect responses of genes that are restricted to small numbers of cells?

We established the toxicogenomic profiles of 11 toxicants. The gene-expression patterns induced by the 11 toxicants are related but sufficiently different to recognize toxicant-specific profiles and developmental stage-specific gene responses were also evident. Moreover, we could detect gene-expression changes at concentrations that do not have phenotypic consequences. We found synergistic effects when a mixture of compounds was applied at low doses, suggesting that the genomic response provides a more sensitive readout than morphological effects.

\section{Results \\ Model compounds cause similar teratological and toxic effects in zebrafish embryos}

We chose 11 model compounds, namely methylmercury chloride ( $\mathrm{MeHg}$ ), $\mathrm{CdCl}_{2}(\mathrm{Cd}), \mathrm{PbCl}_{2}(\mathrm{~Pb}), \mathrm{As}_{2} \mathrm{O}_{3}$ (As), Aroclor 1254 (PCB), acrylamide (AA), tert-butylhydroquinone (tBHQ), 4chloroaniline (4CA), 1,1-bis-(4-chlorophenyl)2,2,2-trichloroethane (DDT), 2,3,7,8-tetrachlorodibenzo-p-dioxin (TCDD) and valproic acid (VA). These are compounds known for their environmental toxicity [24] and VA is a teratogen and an anti-epileptic drug [25]. VA is known to inhibit histone deacetylases and Wnt signaling in mammals, thus adding an additional mode of toxic action [26].

We first established exposure protocols with which one can trigger toxicogenomic alterations with high likelihood and at the same time cause only a small amount of cell death or embryo mortality. We limited the exposure time to 20-24 hours in the expectation of focusing predominantly on primary responses rather than indirect, secondary effects. Finally, we decided to carry out these assays in embryos before they begin to feed, that is, before 120 hours post-fertilization (hpf). We tested a range of toxicant concentrations to determine the one that caused a morphologically visible toxic/teratological effect in the treated embryos after exposure at 96-120 hpf (Figure 1, Table 1, Additional data file 1). We were not able to discriminate unequivocally between toxicant-specific morphological effects (see Figure 1). Frequently the tails were bent, and the animals had difficulty swimming correctly; in some instances they developed pericardial edema (see Figure 1a). Vehicle-treated embryos did not show alterations (see Figure 1l-n) or did so only at very low frequency. Cell death as monitored by acridine orange staining was not, or only rarely, obvious immediately after treatment when animals were sacrificed for microarray analysis. 

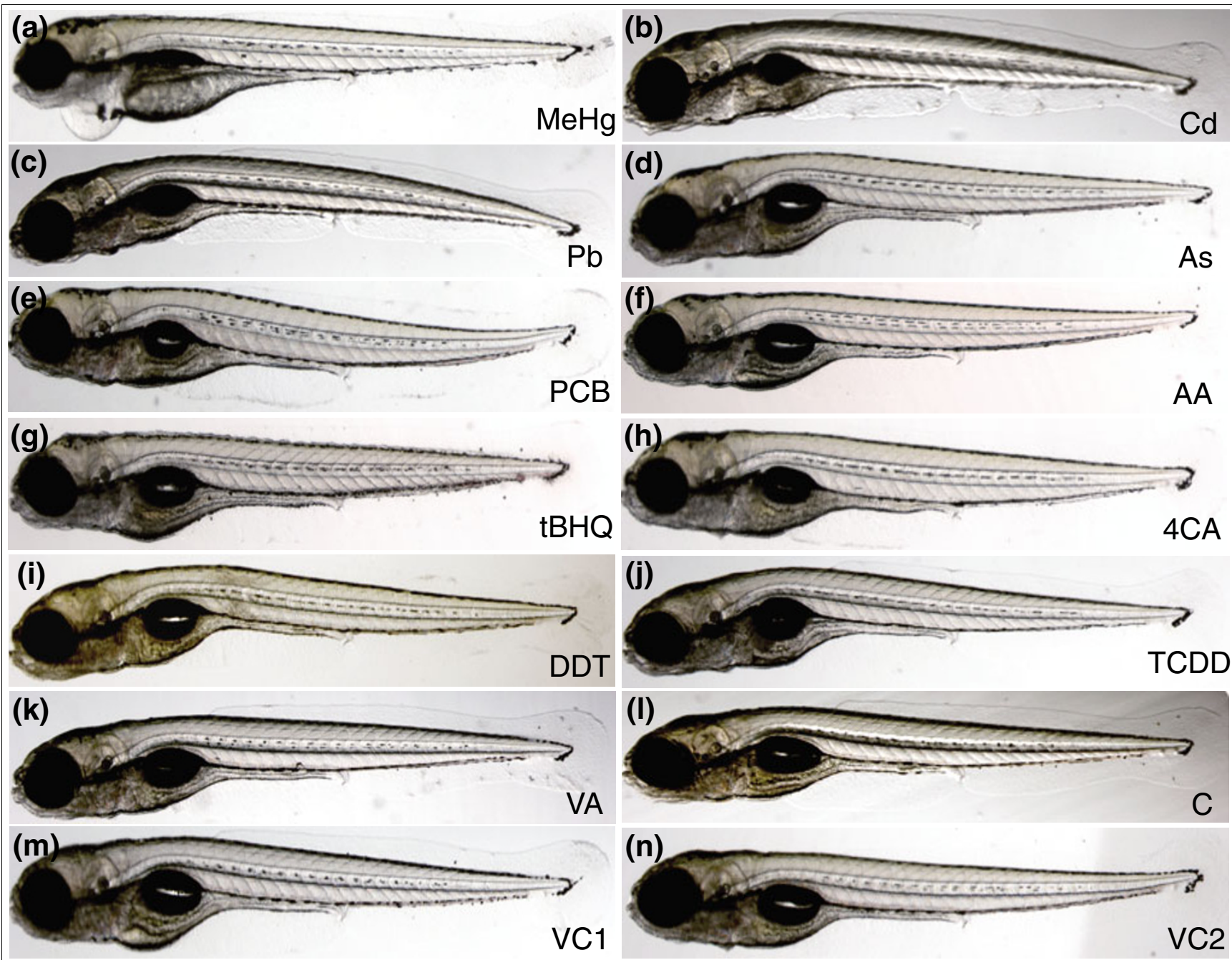

\section{Figure I}

Toxicants induce similar morphological changes in $120 \mathrm{hpf}$ zebrafish embryos. Embryos were treated with (a) methylmercury chloride $(60 \mu \mathrm{g} / \mathrm{l}$, MeHg); (b) $\mathrm{CdCl}_{2}(5 \mathrm{mg} / \mathrm{l}, \mathrm{Cd})$; (c) $\mathrm{PbCl}_{2}(2.8 \mathrm{mg} / \mathrm{l}, \mathrm{Pb})$; (d) $\mathrm{As}_{2} \mathrm{O}_{3}(79 \mathrm{mg} / \mathrm{l}, \mathrm{As})$; (e) Aroclor 1254 (33 mg/l, PCB); (f) acrylamide (7I mg/l, AA); (g) tertbutylhydroquinone (I.7 mg/l, tBHQ); (h) 4-chloroaniline (50 mg/l, 4CA); (i) I,I-bis-(4-chlorophenyl)2,2,2-trichloroethane (I5 mg/l, DDT); (j) 2,3,7,8tetrachlorodibenzo-p-dioxin (500 ng/l, TCDD); (k) valproic acid (50 mg/l, VA); (I) vehicle I control (VCl): embryo water alone (for Cd, $\mathrm{MeHg}, \mathrm{Pb}, \mathrm{As}$, VA, AA treatments); (m) vehicle 2 control (VC2): $0.2 \%$ ethanol control (for 4CA, DDT, tBHQ, PCB); (n) vehicle 3 control (VC3): $0.025 \%$ DMSO, I.4 mg/ I toluene (for TCDD). Embryos showed frequently a bent body axis and developed pericardial edema upon further cultivation.

Between 96 and 120 hpf organogenesis has proceeded so far that the animals feed for the first time [8], marking the end of the embryonic stage. At this stage, gut, liver, pancreas, nervous system, musculature and the cardiovascular system are assumed to reflect adult physiology in many respects, including the response to toxicants. Younger embryonic stages are likely to have different responses to the toxicants. We therefore included two more stages in our initial experiments. The 4-24 hpf treatment covers late blastula, gastrula and segmentation stages, during which the overall body plan is laid down [8]. The treatment phase between 24 and $48 \mathrm{hpf}$ coincides with the onset of organogenesis [8]. Early embryonic stages appear more sensitive to toxicant exposure than the older embryos (compare the 24-48 hpf and 96-120 hpf treatment groups in Table 1). The concentrations of the toxicants were adjusted accordingly (see Table 1 ).

\section{Stage-specific toxicogenomic responses}

To assess possible stage-specific differences, we analyzed and compared the toxicogenomic response to six compounds $\mathrm{MeHg}, \mathrm{Cd}, 4 \mathrm{CA}$, DDT, TCDD, and VA - at the three different stages. We treated several hundred embryos with each of these compounds at each of the three stages (see Materials and methods and Additional data files 1). Principal component analysis (PCA) revealed distinct toxicogenomic responses to exposure with the six toxicants in the 24-48 and 96-120 hpf treatment groups (Figure 2a). Principal components were derived by singular value decomposition (SVD). 
Table I

Summary of microarray experiments

\begin{tabular}{|c|c|c|c|}
\hline Toxicants & Stage & Concentration & Arrays \\
\hline \multirow[t]{6}{*}{$4 \mathrm{CA}$} & $24 \mathrm{hpf}$ & 15 ppm 15 mg/l II $18 \mu \mathrm{M}$ & $8(3)$ \\
\hline & $48 \mathrm{hpf}$ & 50 ppm 50 mg/l $390 \mu \mathrm{M}$ & $6(3)$ \\
\hline & $120 \mathrm{hpf}$ & 50 ppm 50 mg// $390 \mu \mathrm{M}$ & $8(3)$ \\
\hline & $120 \mathrm{hpf}$ & 25 ppm $25 \mathrm{mg} / \mathrm{l} 195 \mu \mathrm{M}$ & $4(1)$ \\
\hline & $120 \mathrm{hpf}$ & 5 ppm 5 mg/l $39 \mu \mathrm{M}$ & $4(1)$ \\
\hline & $120 \mathrm{hpf}$ & 0.5 ppm $0.5 \mathrm{mg} / \mathrm{l} 3.9 \mu \mathrm{M}$ & $4(1)$ \\
\hline \multirow[t]{5}{*}{ DDT } & $24 \mathrm{hpf}$ & 5 ppm 5 mg/l I4 $\mu \mathrm{M}$ & $6(3)$ \\
\hline & $48 \mathrm{hpf}$ & I5 ppm 15 mg/l $42 \mu \mathrm{M}$ & $6(2)$ \\
\hline & $120 \mathrm{hpf}$ & I5 ppm 15 mg/l $42 \mu \mathrm{M}$ & $8(3)$ \\
\hline & $120 \mathrm{hpf}$ & I.5 ppm $1.5 \mathrm{mg} / \mathrm{l} 4.2 \mu \mathrm{M}$ & $4(1)$ \\
\hline & $120 \mathrm{hpf}$ & $0.15 \mathrm{ppm} 0.15 \mathrm{mg} / \mathrm{l} 0.42 \mu \mathrm{M}$ & $4(1)$ \\
\hline \multirow[t]{6}{*}{$\mathrm{Cd}$} & $24 \mathrm{hpf}$ & $0.5 \mathrm{ppm} 0.5 \mathrm{mg} / \mathrm{l} 2.7 \mu \mathrm{M}$ & $8(4)$ \\
\hline & $48 \mathrm{hpf}$ & 5 ppm 5 mg/l $27 \mu \mathrm{M}$ & $8(3)$ \\
\hline & $120 \mathrm{hpf}$ & 5 ppm 5 mg/l $27 \mu \mathrm{M}$ & $8(3)$ \\
\hline & $120 \mathrm{hpf}$ & 2.5 ppm $2.5 \mathrm{mg} / \mathrm{l} \mathrm{I} 3.5 \mu \mathrm{M}$ & $4(2)$ \\
\hline & $120 \mathrm{hpf}$ & $0.5 \mathrm{ppm} 0.5 \mathrm{mg} / \mathrm{l} 2.7 \mu \mathrm{M}$ & $4(2)$ \\
\hline & $120 \mathrm{hpf}$ & $50 \mathrm{ppb} 50 \mu \mathrm{g} / / 0.27 \mu \mathrm{M}$ & $4(2)$ \\
\hline \multirow[t]{5}{*}{ TCDD } & $24 \mathrm{hpf}$ & 150 ppt I50 ng// 0.47 nM & $8(3)$ \\
\hline & $48 \mathrm{hpf}$ & 500 ppt 500 ng/l 1.6 nM & $4(2)$ \\
\hline & $120 \mathrm{hpf}$ & 500 ppt 500 ng/l 1.6 nM & $8(3)$ \\
\hline & $120 \mathrm{hpf}$ & 250 ppt $250 \mathrm{ng} / \mathrm{l} 0.8 \mathrm{nM}$ & $4(1)$ \\
\hline & $120 \mathrm{hpf}$ & 50 ppt $50 \mathrm{ng} / / 0.16 \mathrm{nM}$ & $4(2)$ \\
\hline \multirow[t]{6}{*}{ VA } & $24 \mathrm{hpf}$ & 15 ppm 15 mg/l $12.9 \mu \mathrm{M}$ & $8(3)$ \\
\hline & $48 \mathrm{hpf}$ & 50 ppm 50 mg/l $43 \mu \mathrm{M}$ & $8(3)$ \\
\hline & $120 \mathrm{hpf}$ & 50 ppm 50 mg/l $43 \mu \mathrm{M}$ & $8(3)$ \\
\hline & $120 \mathrm{hpf}$ & $25 \mathrm{ppm} 25 \mathrm{mg} / \mathrm{l} 21.5 \mu \mathrm{M}$ & $4(1)$ \\
\hline & $120 \mathrm{hpf}$ & 5 ppm 5 mg// $4.3 \mu \mathrm{M}$ & $4(1)$ \\
\hline & $120 \mathrm{hpf}$ & 0.5 ppm $0.5 \mathrm{mg} / \mathrm{l} 0.43 \mu \mathrm{M}$ & $4(1)$ \\
\hline \multirow[t]{5}{*}{$\mathrm{MeHg}$} & $24 \mathrm{hpf}$ & 50 ppb $50 \mu \mathrm{g} / / 0.20 \mu \mathrm{M}$ & $8(3)$ \\
\hline & $48 \mathrm{hpf}$ & $60 \mathrm{ppb} 60 \mu \mathrm{g} / / 0.24 \mu \mathrm{M}$ & $6(2)$ \\
\hline & $120 \mathrm{hpf}$ & $60 \mathrm{ppb} 60 \mu \mathrm{g} / / 0.24 \mu \mathrm{M}$ & $10(3)$ \\
\hline & $120 \mathrm{hpf}$ & $30 \mathrm{ppb} 30 \mu \mathrm{g} / / 0.12 \mu \mathrm{M}$ & $4(2)$ \\
\hline & $120 \mathrm{hpf}$ & 6 ppb $6 \mu g / / 0.024 \mu \mathrm{M}$ & $4(2)$ \\
\hline \multirow[t]{2}{*}{ As } & $120 \mathrm{hpf}$ & 79 ppm $79 \mathrm{mg} / \mathrm{l} 400 \mu \mathrm{M}$ & $8(3)$ \\
\hline & $120 \mathrm{hpf}$ & 7.9 ppm $7.9 \mathrm{mg} / \mathrm{l} 40 \mu \mathrm{M}$ & $4(1)$ \\
\hline \multirow[t]{2}{*}{$\mathrm{Pb}$} & $120 \mathrm{hpf}$ & $2.8 \mathrm{ppm} 2.8 \mathrm{mg} / \mathrm{l} 10 \mu \mathrm{M}$ & $8(3)$ \\
\hline & $120 \mathrm{hpf}$ & $0.28 \mathrm{ppm} 0.28 \mathrm{mg} / \mathrm{l} \mathrm{I} \mu \mathrm{M}$ & $4(1)$ \\
\hline PCB & $120 \mathrm{hpf}$ & 33 ppm 33 mg/l $100 \mu \mathrm{M}$ & $8(3)$ \\
\hline$A A$ & $120 \mathrm{hpf}$ & 7I ppm 7l mg/l I mM & $8(3)$ \\
\hline $\mathrm{tBHQ}$ & $120 \mathrm{hpf}$ & I.7 ppm $1.7 \mathrm{mg} / \mathrm{l} \mathrm{I} 0 \mu \mathrm{M}$ & $8(3)$ \\
\hline Mixture & $120 \mathrm{hpf}$ & $\mathrm{Pb} \mathrm{I} \mu \mathrm{M}, \mathrm{Cd} 0.27 \mu \mathrm{M}$, As $40 \mu \mathrm{M}, \mathrm{Hg} 0.024 \mu \mathrm{M}$ & $6(3)$ \\
\hline
\end{tabular}

Embryos were either treated from 4 to $24(24 \mathrm{hpf})$ or from 24 to $48 \mathrm{hpf}$ ( $48 \mathrm{hpf}$ ) or from 96 to $120 \mathrm{hpf}$ ( 5 days). Arrays, total number of microarray hybridizations. Numbers in brackets indicate the number of independent biological repeats. 4CA, 4-chloroaniline; DDT, I, I-bis-(4-chlorphenyl)2,2,2-trichlorethane; Cd, cadmium chloride; TCDD, 2,3,7,8-tetrachlorodibenzo-p-dioxin; VA, valproic acid; MeHg, methylmercury chloride; As, arsenic (III) oxide; Pb, lead (II) chloride; AA, acrylamide, PCB, Aroclor 1254; tBHQ, tert-butylhydroquinone. 


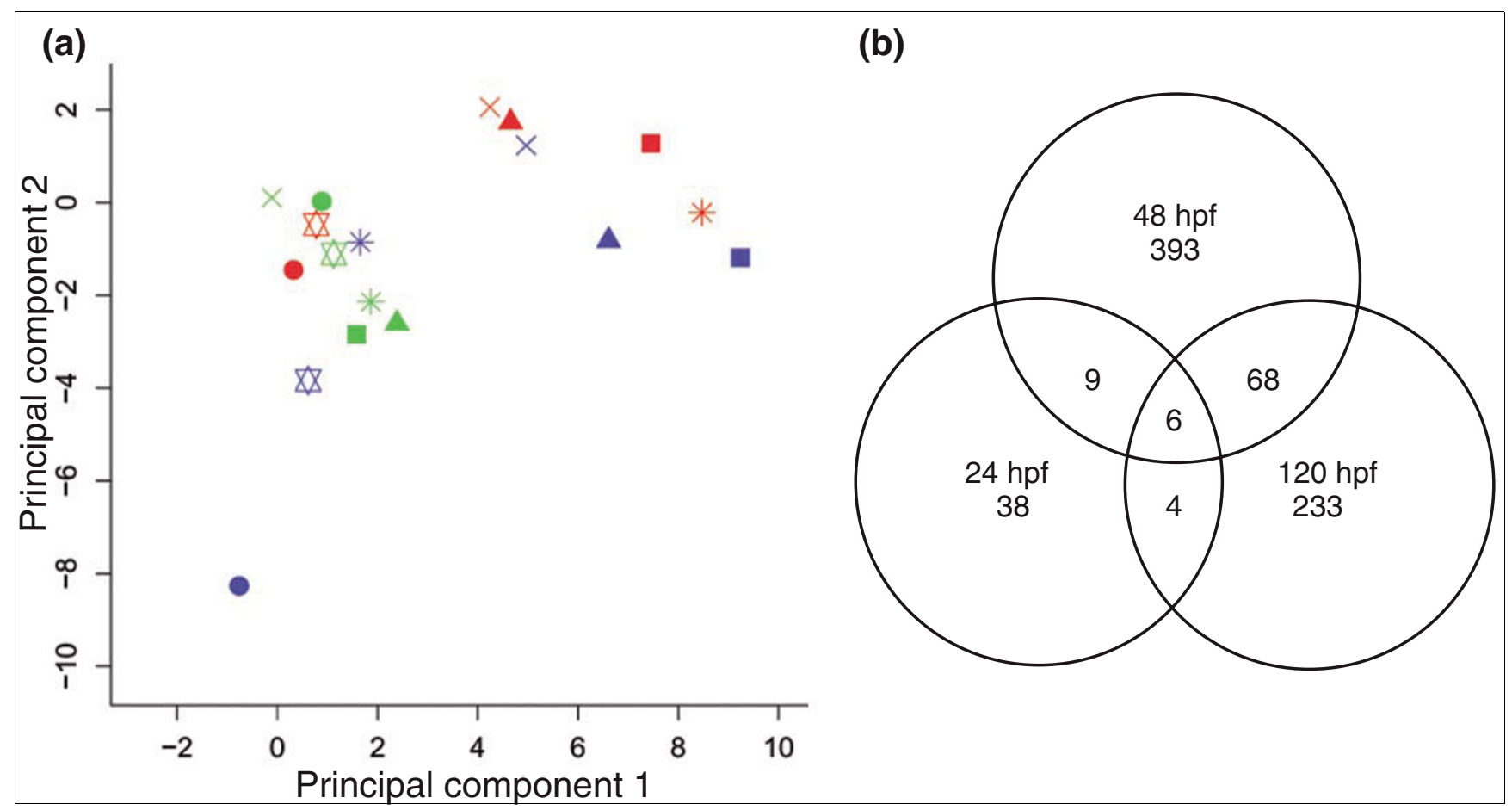

\section{Figure 2}

Distinct toxicogenomic expression profiles are induced by different toxicants. (a) Principal component analysis of the toxicogenomic profiles derived from three different embryonic stages. Embryos were exposed to vehicle controls or to one of six chemicals for the periods 4-24 hpf (green), 24-48 hpf (blue), or $96-120 \mathrm{hpf}$ (red). Circles, TCDD: I50 ng/l (24 hpf), $500 \mathrm{ng} / \mathrm{l}$ (48 hpf), $500 \mathrm{ng} / \mathrm{l}$ (I20 hpf). Squares, MeHg: $50 \mu \mathrm{g} / \mathrm{l}(24 \mathrm{hpf}), 60 \mu \mathrm{g} / \mathrm{l}(48 \mathrm{hpf}), 60 \mu \mathrm{g} / \mathrm{l}$ (I20 hpf). Triangles, VA: $15 \mathrm{mg} / \mathrm{l}(24 \mathrm{hpf}), 50 \mathrm{mg} / \mathrm{l}$ ( $48 \mathrm{hpf}), 50 \mathrm{mg} / \mathrm{l}$ (120 hpf). Crosses, 4 CA: $15 \mathrm{mg} / \mathrm{l}(24 \mathrm{hpf}), 50 \mathrm{mg} / \mathrm{l}$ ( $48 \mathrm{hpf}), 50 \mathrm{mg} / \mathrm{l}$ (I20 hpf). Asterisks, Cd $500 \mu \mathrm{g} / \mathrm{l}(24 \mathrm{hpf}), 5 \mathrm{mg} / \mathrm{l}(48 \mathrm{hpf}), 5 \mathrm{mg} / \mathrm{l}(120 \mathrm{hpf})$. Stars, DDT: $5 \mathrm{mg} / \mathrm{l}(24 \mathrm{hpf}), 15 \mathrm{mg} / \mathrm{l}(48 \mathrm{hpf}), 15 \mathrm{mg} / \mathrm{l}(120 \mathrm{hpf})$. While the transcriptional profiles of the 4-24 hpf treatment group (green symbols) cluster closely, characteristic gene-expression profiles were induced by the 24-48 hpf (blue symbols) and the 96$120 \mathrm{hpf}$ (red symbols) exposures to each of the different toxicants. (b) Venn diagram comparing the number of genes induced at the three stages by all six toxicants. Numbers indicate numbers of regulated or co-regulated genes at the different stages (more than I.95-fold change and adjusted $p_{\mathrm{adj}}<0.025$ ).

SVD is based on the decomposition of the gene-expression matrix, whose entries are the log-transformed fold changes (M values) of gene expression, into unique orthonormal superpositions of genes and treatments. Expression changes of at least twofold and a $p_{\text {adj }}<0.025$ were taken into account.

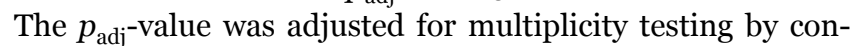
trolling the false discovery rate [27].

The differences between the transcriptional profiles induced by the six toxicants were less prominent in the datasets from the 4-24 hpf treatment groups (see Figure 2a). This may be due to the fact that different toxicants caused similar gene effects at 24 hpf. For example, the expression of the gene for fast muscle troponin T (BE693169) was downregulated by Cd, MeHg, TCDD, and VA in embryos treated between 4 and 24 hpf but not at later stages (data not shown). Furthermore, many genes that are involved in organ physiology may not yet be responsive by $24 \mathrm{hpf}$, as organ development has not proceeded far enough. In agreement with this, the expression levels of only 57 genes were significantly altered by the $4-24 \mathrm{hpf}$ treatment. In contrast, the expression levels of 476 and 311 genes were significantly affected by the 24-48 hpf and 96-120 hpf treatment regimens, respectively (see Figure $2 b$ ). Moreo- ver, very few genes in the 4-24 hpf treatment set overlapped with the 24-48 and 96-120 hpf treatment groups (15 and 10 genes, respectively). The latter groups (24-48 $\mathrm{h}$ and 96-120 hpf) shared more gene responses (74 genes) but 393 and 233 gene responses were stage specific (see Figure 2b). The smaller number of affected genes in the 4-24 hpf regimen may also have been caused by the lower concentrations of toxicants that we had to apply to ensure sufficient survival at these younger stages. Irrespective of this, these data indicate a high stage specificity of the toxicogenomic effects in the three treatment windows.

\section{The toxicogenomic responses triggered by different toxicants are highly specific}

We focused further analysis on the 96-120 hpf stage and used the full set of 11 toxicants by including treatments with AA, $\mathrm{PCB}, \mathrm{As}, \mathrm{tBHQ}$ and $\mathrm{Pb}$. Replicate hybridizations with mRNA from at least three independent toxicant treatments were performed (see Table 1). Toxicant effects were clustered based on their Euclidean distance to each other and the similarity of gene responses was determined by a Pearson correlation proximity measure. The expression profiles summarize clustering results for a subset of 199 genes across all 11 toxicant 


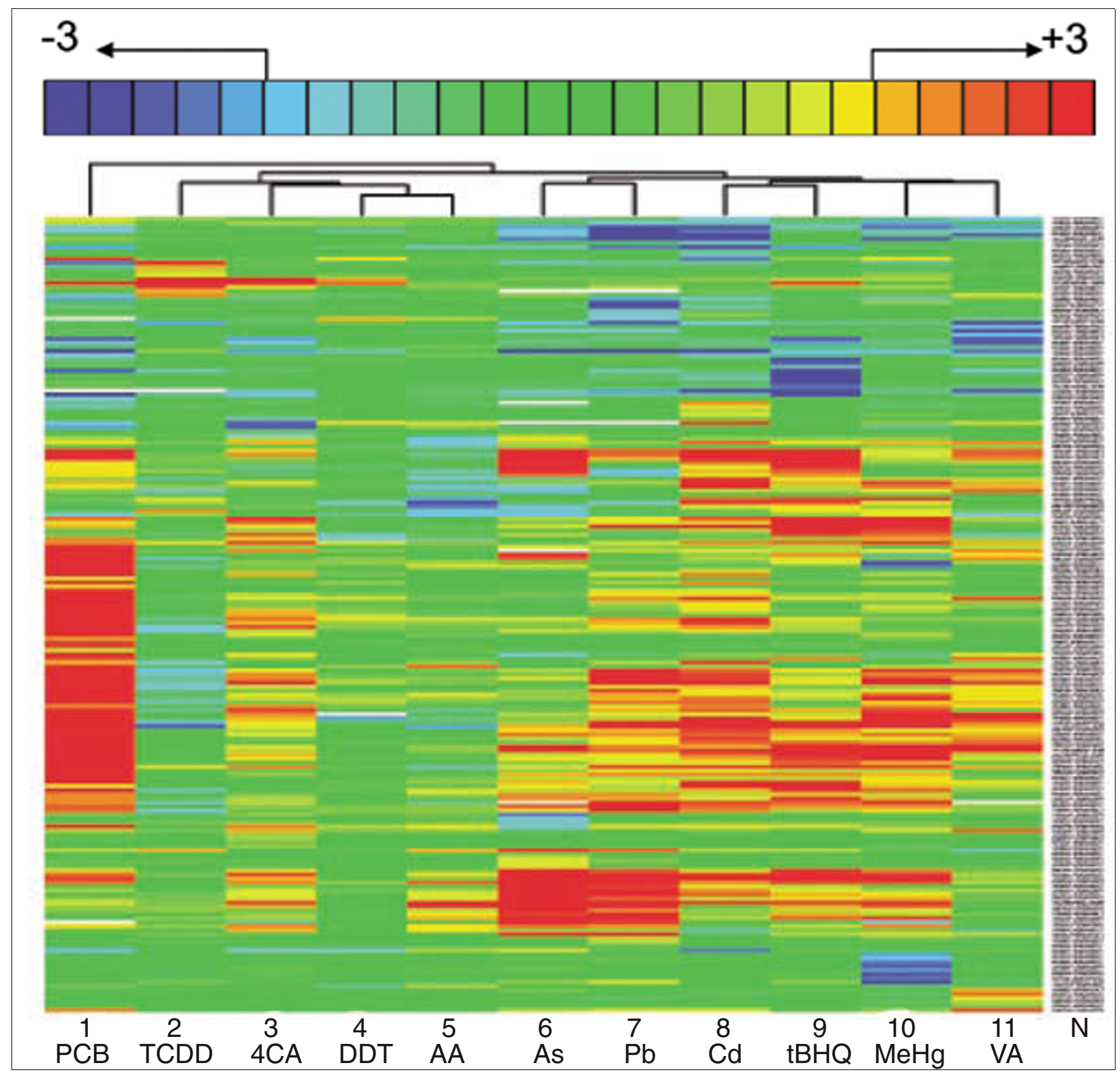

Figure 3

Toxicants induce highly specific toxicogenomic profiles. Hierarchical clustering of gene responses in embryos treated between 96 and I20 hpf with PCB

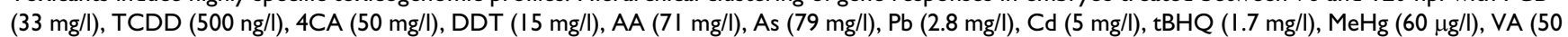
$\mathrm{mg} / \mathrm{l})$. For each toxicant exposure, vehicle controls were carried out in parallel. The gene names are indicated $(\mathrm{N})$ and are legible upon magnification of the PDF version of this figure. The key at the top indicates the color code for fold changes ranging from threefold upregulated $(+3$, red) to threefold downregulated $(-3$, blue). Fold changes greater than three are not indicated explicitly but are included. Only genes are listed whose mRNA levels changed by more than twofold $\left(p_{\text {adj }}<0.025\right)$ in at least one of the treatments. The data represent the average over all biological and technical repeats (see Table I).

responses (Figure 3). The gene-selection criteria applied take into account the extent and significance of changes in gene expression (at least twofold, $p_{\text {adj }}<0.025$ ) as well as differences and similarities in expression changes between toxicants (see Materials and methods). Distinct patterns of gene expression were noted for each of the 11 compounds. However, similarities in gene responses were also detected. One group of chemicals with related gene responses comprises $\mathrm{Pb}$, As, Cd, tBHQ, MeHg and VA (see Figure 3, lanes 6 to 11). Another subgroup of related responses was induced by 
Table 2

\begin{tabular}{|c|c|c|c|c|c|c|c|c|c|c|c|}
\hline Test & $4 C A$ & $\mathrm{Cd}$ & DDT & $\mathrm{MeHg}$ & TCDD & VA & $A A$ & As & $\mathrm{Pb}$ & PCB & $\mathrm{tBHQ}$ \\
\hline $\mathrm{Pb}$ & 6.15 & 6.78 & 8.66 & 6.76 & 10.91 & 7.96 & 7.62 & 6.32 & 5.01 & 10.66 & 6.81 \\
\hline DDT & 6.74 & 9.86 & 4.51 & 8.79 & 7.79 & 8.01 & 5.39 & 10.38 & 8.96 & 10.05 & 9.13 \\
\hline $4 \mathrm{CA}$ & $6.87^{*}$ & 10.96 & $6.69 *$ & 9.47 & 8.82 & 8.87 & $6.99 *$ & 11.21 & 8.42 & 10.75 & 9.42 \\
\hline TCDD & 8.55 & 12.43 & 6.78 & 11.01 & 5.42 & 10.37 & 7.61 & 10.76 & $12.6 \mid$ & 15.63 & 10.62 \\
\hline As & 9.14 & 9.56 & 10.93 & 9.74 & 12.46 & 9.89 & 10.18 & 6.88 & 7.51 & 11.32 & 7.51 \\
\hline $\mathrm{Pb}$ & 7.25 & 7.95 & 10.05 & 7.38 & 12.06 & 8.62 & 8.65 & 9.58 & 4.22 & 9.91 & 7.70 \\
\hline PCB & 9.84 & 9.30 & 13.17 & 10.23 & $15.0 \mid$ & 10.01 & 11.78 & 12.77 & 10.62 & 3.93 & 10.40 \\
\hline As & 9.18 & 9.99 & 9.92 & 10.20 & 11.53 & 10.16 & 9.43 & 5.48 & 7.84 & 12.40 & 7.67 \\
\hline TBHQ & 8.79 & 7.49 & 11.32 & 9.24 & 11.52 & 10.29 & 10.98 & 8.93 & 9.77 & 11.31 & 6.33 \\
\hline PCB & 8.37 & 7.74 & 12.06 & 8.88 & 13.65 & 8.54 & 10.63 & 11.79 & 10.22 & 5.7 I & 9.08 \\
\hline AA & 7.18 & 10.79 & 4.29 & 9.28 & 7.21 & 8.63 & 3.56 & 7.67 & 8.12 & 13.04 & 8.86 \\
\hline TBHQ & 7.49 & 7.26 & 11.22 & 8.30 & 11.66 & 9.00 & 10.40 & 9.57 & 9.58 & 10.47 & 5.41 \\
\hline $\mathrm{Cd}$ & 8.32 & 6.67 & 10.76 & 8.39 & 12.79 & 8.90 & 10.16 & 10.89 & 6.96 & 8.05 & 8.15 \\
\hline VA & 6.43 & 8.25 & 6.47 & 7.57 & 9.04 & 4.57 & 6.15 & 9.56 & 8.02 & 10.24 & 8.33 \\
\hline $\mathrm{AA}$ & 10.26 & 14.38 & 7.09 & 12.23 & 9.61 & 11.59 & 6.25 & 11.26 & 10.54 & 13.89 & 11.84 \\
\hline
\end{tabular}

Embryos were exposed from 96 to 120 hpf with the test compounds (Test). The table gives the Euclidean distances between the expression profiles for test compounds and the $1 \mathrm{I}$ toxicants. Bold type indicates the correct match. An ambiguous score was obtained in the case of 4CA (*) with three closely matching expression profiles. Note that the assessment of each test compound is based on one experiment.

TCDD, 4CA, DDT and AA (see Figure 3, lanes 2-5), whereas the PCB triggered a more distinct expression profile (see Figure 3 , lane 1).

As verification, we carried out blind tests to identify the chemicals by their induced gene-expression profile. Fourteen out of the 15 chemicals were unambiguously identified (Table 2). In the case of $4 \mathrm{CA}$, close matches were scored to the $4 \mathrm{CA}$, the DDT and the AA response profiles (see Table 2). Thus, we identified the correct group of chemicals (see Figure 3, lanes 2-4). Taken together, the results from these blind trials underscore the reliability of the toxicogenomic profiles and furthermore suggest that it is possible to derive signatures of toxicogenomic responses predictive for specific chemicals or chemical groups from whole animal exposure experiments.
The induced genes fell into different gene ontology groups such as genes involved in combating oxidative stress (Table 3) and genes encoding chaperones (Table 4). Another major class of genes that was significantly regulated by a number of toxicants comprised solute carriers (Table 5). We also carried out a computational analysis of the affected genes using the GoTreeMachine algorithm to identify more complex pathways and processes (Additional data files 2-9). An inflammatory response was induced by several compounds (As, 4CA, $\mathrm{Cd}, \mathrm{MeHg}, \mathrm{Pb}, \mathrm{PCB}$ and tBHQ), whereas inductions characteristic of an immune response were evoked by $\mathrm{MeHg}$ and tBHQ. The latter compound also triggered genes involved in G-protein-coupled signaling and phototransduction. Induction of genes with a function in base-excision repair was noted in the case of exposure to As and PCB, suggesting that these compounds cause DNA damage in the embryo.

Table 3

\begin{tabular}{|c|c|c|c|c|c|c|c|c|c|c|}
\hline Gene name & Gene ID & $\mathrm{AA}$ & As & $4 C A$ & $\mathrm{Cd}$ & $\mathrm{MeHg}$ & $\mathrm{Pb}$ & PCB & $\mathrm{tBHQ}$ & VA \\
\hline Peroxiredoxin I & $\mathrm{B} 1980610$ & 3.9 & 13.6 & 4.1 & 3.1 & 7.7 & 9.9 & & 7.5 & \\
\hline Thioredoxin & $\mathrm{B} 1864190$ & & 14.2 & 3.5 & 4 & 4.4 & 8.1 & 2.5 & 6.1 & \\
\hline Glutathione S-transferase omega I & AW0I9036 & 3 & 6.3 & 2.1 & & 2.6 & 3.5 & & 2.2 & \\
\hline Glutathione S-transferase pi & AF285098 & 2 & 4.1 & & & 3.2 & 5.9 & & 2.7 & \\
\hline Glutathione S-transferase omega 2 & $\mathrm{~B} 1979918$ & & 5.6 & & 2.7 & & 5.2 & & 2.1 & \\
\hline Thioredoxin interacting protein & $\mathrm{B} 1892352$ & & & & 2 & & & & & 2 \\
\hline Glutathione peroxidase & AW232474 & & & & & -4.2 & & & & \\
\hline
\end{tabular}

Gene ID refers to the accession number in GenBank. 
Table 4

\begin{tabular}{|c|c|c|c|c|c|c|c|c|}
\hline Gene name & Gene ID & As & $4 C A$ & $\mathrm{Cd}$ & $\mathrm{Pb}$ & $\mathrm{PCB}$ & $\mathrm{tBHQ}$ & VA \\
\hline \multirow[t]{2}{*}{ Stress protein HSP70 } & $A B 062116$ & 10.1 & 2.2 & 7 & 2.5 & 5.4 & 12.3 & 2.7 \\
\hline & AF210640 & 10.9 & & 6.6 & 2.5 & 5 & 10.8 & 2.7 \\
\hline Hsp70 (2) & AF006007 & 7.6 & & 6.3 & 2.1 & 4.6 & 10.1 & 2.4 \\
\hline Heat shock protein HSP 90 -alpha & AF068773 & 2.6 & & & & & & \\
\hline Heat shock cognate $70 \mathrm{kDa}$ protein & BM024785 & 3 & & & & & & \\
\hline DnaJ (Hsp40) homolog, family A, member I & $\mathrm{B} 1891737$ & 3.6 & & & & & 3.6 & \\
\hline Ahsal protein & BMI03957 & 2.2 & & & & & 2.1 & \\
\hline
\end{tabular}

Table 5

Solute carrier family genes and their response to toxicants

\begin{tabular}{|c|c|c|c|c|c|c|c|c|}
\hline Gene name & Gene ID & As & $4 C A$ & $\mathrm{Cd}$ & $\mathrm{MeHg}$ & $\mathrm{Pb}$ & PCB & VA \\
\hline Solute carrier family 16 member 9 (I) & BE0I6639 & & 2.5 & 2.9 & 2.4 & 3.6 & 4.1 & 2.3 \\
\hline Solute carrier family 16 member 9 (2) & BI474827 & & 3.4 & 4.3 & 4.8 & 4.7 & 7.9 & 3 \\
\hline Solute carrier family 16 member 6 & AW421040 & & & & 2.9 & 4 & 4.6 & 2.9 \\
\hline Solute carrier family 2 member 5 & Al477656 & 2.1 & & & & 2.1 & 2.5 & \\
\hline Solute carrier family 6 member 8 & $\mathrm{~B} 1980828$ & & & 2 & & 2.2 & 2.4 & \\
\hline Solute carrier family 43 , member 2 & BI887324 & & & & & & 2.1 & \\
\hline Solute carrier family 3 & BG9855I8 & & & & & & 2.1 & \\
\hline Solute carrier family 20 (phosphate) member I & $\mathrm{B} 1890772$ & & & & & & 2.2 & \\
\hline \multirow[t]{2}{*}{ Solute carrier family 6 (GABA) member I } & BFI570II & & & & & & & -3.1 \\
\hline & BI563084 & & & & & & & -2.1 \\
\hline
\end{tabular}

\section{Identification of tissue-specific genes}

We next verified the observed gene responses by methods other than microarray hybridization. First, the changes in gene expression were confirmed by re-evaluating a subset of gene responses by semi-quantitative reverse transcription PCR (RT-PCR). Out of 14 gene responses analyzed, all showed the up- or downregulation expected from the array data (Figure 4). This suggests that the changes in transcript levels measured by the microarray hybridizations reflect genuine responses to the toxicants.

We used in situ hybridization with selected probes to toxicant-treated and control embryos to assess the tissue-specific expression patterns of the response genes and whether these are altered in response to toxicant. Cytochrome P4501A1 mRNA (AFo57713) was induced by $500 \mathrm{ng} / \mathrm{l}$ TCDD in endothelial cells (15/15 embryos, Figure $5 \mathrm{a}, \mathrm{b})$. The levels of glutathione peroxidase 1 (AW232474) mRNA in stomach and gut were repressed by $60 \mu \mathrm{g} / \mathrm{l} \mathrm{MeHg}(11 / 15$ embryos, Figure $5 \mathrm{c}, \mathrm{d}$ ), in agreement with microarray and RT-PCR data (see Figure 4).
The neuromasts of the zebrafish lateral line are very sensitive to a number of compounds including $\mathrm{CdCl}_{2}$ [28-30]. the mRNA for oncomodulin A (also called parvalbuminza), which is expressed in the hair cells and supporting cells of neuromasts in untreated embryos, is barely detectable in the neuromasts of embryos treated with $500 \mu \mathrm{g} / \mathrm{l} \mathrm{CdCl}{ }_{2}(13 / 15$ embryos, Figure $5 \mathrm{e}, \mathrm{f})$, in concordance with the Cd-induced, 4.4-fold decrease of oncomodulin A mRNA measured by microarray hybridization (see Figure 4). In contrast, thioredoxin-like mRNA (BI864190) is upregulated in hair cells (12/ 13 embryos, Figure 5g,h) in response to Cd. This suggests that $\mathrm{Cd}$ does not cause a complete loss of hair cells, even though staining with the dye DASPEI suggests that hair cells are strongly reduced (data not shown). The thioredoxin-like mRNA is also expressed in selected areas of the brain. These regions show also increased levels of expression in response to Cd (data not shown). In summary, these in situ expression studies show that the microarray procedure used permits detection of organ- and cell-specific gene responses with very high sensitivity. Moreover, these results also suggest that the gene responses occur in almost all of the embryos exposed to the toxicants. 


\begin{tabular}{|c|c|c|c|c|c|}
\hline Toxicants & Gene ID & Gene name & \begin{tabular}{|c|}
$\begin{array}{c}\text { Fold } \\
\text { change }\end{array}$ \\
\end{tabular} & $\begin{array}{c}\text { cycle } \\
\text { numbers }\end{array}$ & Treat \\
\hline \multirow[t]{2}{*}{ TCDD } & Al397347 & Similarity to keratin type 1 (human) & -2.6 & 30 & $=$ \\
\hline & AF057713 & Danio rerio cytochrome $\mathrm{p} \mathrm{4501 \textrm {A }}$ & 37.7 & 25 & $=$ \\
\hline$\overline{\mathrm{DDT}}$ & $\mathrm{BI} 533854$ & Weakly similar to c-type lectin & -2.1 & 25 & 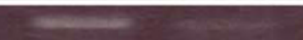 \\
\hline \multirow[t]{5}{*}{$\mathrm{Cd}$} & BE201681 & Danio rerio Oncomodulin A & -4.4 & 25 & - \\
\hline & AW174507 & Danio rerio materix metalloprotinase 9 & 8.8 & 25 & 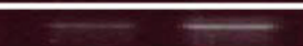 \\
\hline & AF210640 & Danio rerio HSP 70 & 8.2 & 20 & 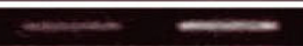 \\
\hline & AW305943 & Danio rerio materix metalloproteinase 13 & 7.5 & 30 & 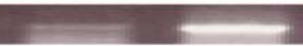 \\
\hline & $\mathrm{BI} 864190$ & Similarity to thioredoxin & 4.3 & 25 & - \\
\hline \multirow[t]{4}{*}{$\mathrm{Hg}$} & AW232474 & Danio rerio glutathione peroxidase 1 & -4.7 & 25 & $=$ \\
\hline & $\mathrm{B} \mid 980610$ & Similarity to natural killer cell enhacning factor & 3.9 & 25 & $\underline{z}$ \\
\hline & $\mathrm{BI} 864190$ & Similarity to thioredoxin & 3.8 & 25 & 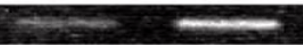 \\
\hline & BG727181 & unknown & 3.2 & 30 & $=$ \\
\hline \multirow[t]{2}{*}{ VA } & AY050500 & Danio rerio cone transducin alpha subunit & -2.4 & 25 & $\mathbf{3}$ \\
\hline & AW422298 & Similarity to transcription factor ATF-3 & 4.2 & 25 & - \\
\hline \multirow[t]{2}{*}{$4 \mathrm{CA}$} & $\mathrm{BI} 843145$ & unknown & -2.8 & 30 & 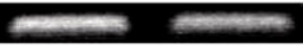 \\
\hline & $\mathrm{B} \mid 980610$ & Similarity to natural killer cell enhancin g factor & 3.9 & 30 & $\operatorname{mon} 20$ \\
\hline As & $\mathrm{Bl} 864190$ & Similarity to thioredoxin & 11.4 & 30 & $\operatorname{mos}$ \\
\hline Embryo medium & $\beta$-actin & & ND & 30 & - \\
\hline $0.2 \%$ ethanol & $\beta$-actin & & ND & 30 & $\longrightarrow$ \\
\hline $\begin{array}{l}0.025 \% \mathrm{DMSO}+1.4 \\
\mathrm{mg} / \mathrm{l} \text { toluene }\end{array}$ & $\beta$-actin & & ND & 30 & 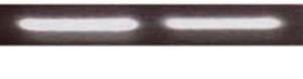 \\
\hline
\end{tabular}

Figure 4

RT-PCR analysis confirms selected gene responses. Embryos were exposed to the indicated toxicants $(500 \mathrm{ng} / \mathrm{l} \mathrm{TCDD;} 15 \mathrm{mg} / \mathrm{l} \mathrm{DTT;} 5 \mathrm{mg} / \mathrm{l} \mathrm{Cd;60 \mu g/l}$ $\mathrm{MeHg} ; 50 \mathrm{mg} / \mathrm{l} \mathrm{VA} ; 50 \mathrm{mg} / \mathrm{l} 4 \mathrm{CA} ; 79 \mathrm{mg} / \mathrm{l} \mathrm{As}$ ) or vehicle alone (embryo medium or $0.2 \%$ ethanol or $0.025 \%$ DMSO, I.4 mg/l toluene) between 96 and I 20 hpf. (a) cDNA was synthesized and subjected to PCR with primers specific for the selected genes indicated. Gene ID refers to the accession number in GenBank. The number of temperature cycles (cycle numbers) for every set of amplifications is indicated. The fold-change column summarizes the results from the microarray experiments for comparison with the RT-PCR results shown in (b). See legend of Figure I for details of treatments and controls. $\beta$ actin mRNA was used as a toxicant-insensitive reference. ND, not determined, as the actin gene response fell into the class of nonregulated genes in the microarray results.

\section{The genome responds to very low toxicant concentrations}

The concentrations of the toxicants were adjusted in the initial experiments so that they caused morphologically visible defects in exposed animals. We asked next whether one could measure changes in the expression profiles at lower concentrations that do not have apparent morphological effects. TCDD, DDT, Cd, 4CA, MeHg, and VA were used as a set of test compounds. We could detect significant changes in gene expression (at least twofold and $p_{\text {adj }}<0.025$ ) in response to $0.5 \mathrm{mg} / \mathrm{l} \mathrm{Cd}, 6 \mu \mathrm{g} / \mathrm{l} \mathrm{MeHg}, 5 \mathrm{mg} / \mathrm{l} \mathrm{VA}, 25 \mathrm{mg} / \mathrm{l}$ 4CA, $15 \mathrm{mg} / \mathrm{l}$ DDT, and $50 \mathrm{ng} / \mathrm{l}$ TCDD (Figure 6a-c, Table 6, and data not shown). With the exception of $6 \mu \mathrm{g} / \mathrm{l} \mathrm{MeHg}$ and $25 \mathrm{mg} / \mathrm{l} 4 \mathrm{CA}$, these low concentrations did not cause obvious morphological or behavioral defects (data not shown), suggesting that this assay can detect responses to toxicant concentrations that do not cause acute morphological effects. It is clear, however, that the number of genes with a significant response to the toxicants decreases (see Table 6). Cytochrome P4501a1 was fivefold upregulated by $50 \mathrm{ng} / \mathrm{l} \mathrm{TCDD}$, oncomodulin A was reduced 4.5 -fold by $0.5 \mathrm{mg} / \mathrm{l} \mathrm{Cd}$ and peroxiredoxin was still 3.5-fold induced by $6 \mu \mathrm{g} / \mathrm{l} \mathrm{MeHg}$. Thus, even though fewer genes respond to these lower concentrations, the measured changes in transcript levels are robust.

\section{Complex synergistic effects are evident in toxicogenomic responses to compound mixtures}

In the environment we are normally confronted with compound mixtures rather than pure substances. The components of these mixtures could act synergistically, thereby potentiating the toxic effect [31]. We therefore investigated whether synergistic effects of compound mixtures can be observed in toxicogenomic profiles. To this end, 96-hpf embryos were exposed to a mixture of low concentrations of $\mathrm{Cd}(50 \mu \mathrm{g} / \mathrm{l}), \mathrm{Pb}(280 \mu \mathrm{g} / \mathrm{l}), \mathrm{MeHg}(6 \mu \mathrm{g} / \mathrm{l})$ and As (7.9 mg/l). About twice as many genes ( 158 genes) were significantly upor downregulated (absolute change at least twofold, $p_{\text {adj }}<$ o.025) than the sum of the genes regulated by exposure to the 


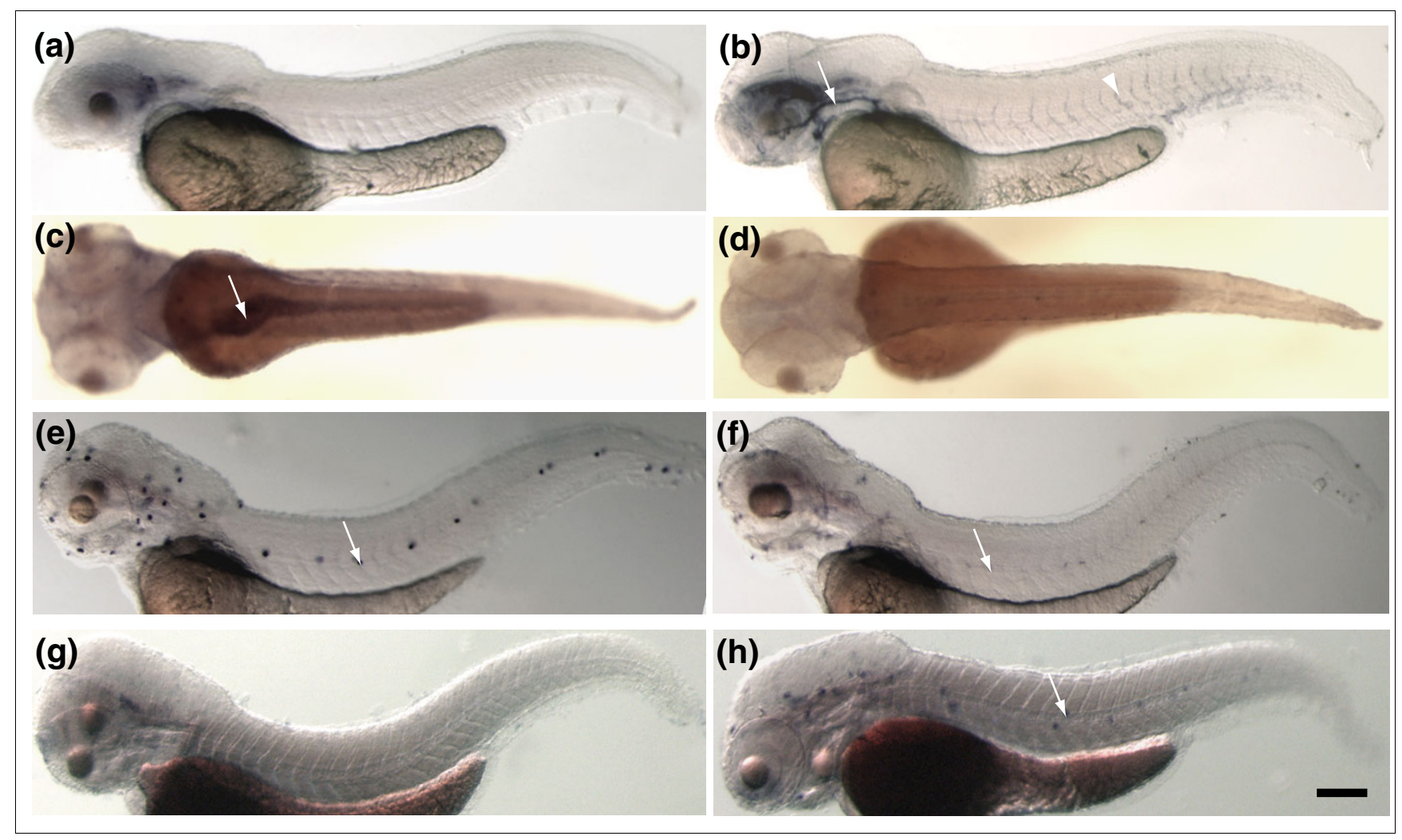

\section{Figure 5}

Examples of toxicant-responsive genes that are expressed in a highly tissue-restricted manner. (a) 48 hpf vehicle 3 control. Figure I indicated the exposure embryo from 96 to $120 \mathrm{hpf}$ and (b) $500 \mathrm{ng} / \mathrm{I} \mathrm{TCDD}$-treated embryos hybridized to a cytochrome P450 IAI antisense probe. TCDD-treated embryos showed increased levels of cytochrome P450IAI mRNA in blood vessels Arrow, primary head sinus, arrowhead, intersegmental vessel. (c) 72 hpf vehicle control I and (d) $60 \mu \mathrm{g} / \mathrm{M} \mathrm{MeHg-exposed} \mathrm{embryos} \mathrm{hybridized} \mathrm{to} \mathrm{a} \mathrm{glutathione} \mathrm{peroxidase} \mathrm{I} \mathrm{probe.} \mathrm{Embryos} \mathrm{showed} \mathrm{a} \mathrm{reduction} \mathrm{of} \mathrm{mRNA}$ levels in the gut (arrow). Embryos were treated from 4 to $72 \mathrm{hpf}$ and were then fixed for in situ processing. (e) Control embryo and (f) $500 \mu \mathrm{g} / \mathrm{l} \mathrm{CdCl} \mathrm{L}_{-}$ treated embryo hybridized to oncomodulin A antisense mRNA. Oncomodulin A mRNA levels are downregulated in the hair cells of the lateral-line organ (arrow) in response to $\mathrm{Cd}$ exposure. (g) Control and (h) Cd-treated embryos hybridized to a thioredoxin antisense probe. Thioredoxin is upregulated in the hair cells of the neuromasts (arrow). Embryos are oriented anterior to the left and dorsal up (a,b,e-h) or with dorsal side facing (c,d). Scale bar represents $220 \mu \mathrm{m}$.

individual toxicants ( 81 genes: Cd 48 genes; As 12 genes; $\mathrm{MeHg} 5$ genes; $\mathrm{Pb} 16$ genes). Complex expression profiles composed of both additive and synergistic as well as novel patterns of gene responses (at least twofold change, $p_{\text {adj }}<$ 0.025; Figure 6d) were scored for the mixture. In the case of the genes with similarity to peroxiredoxin (BI980610) or the solute carrier family members 6 and 9 (BEo16639, AW421040), the response to the mixture appears to be purely additive (see Figure 6d, dots; Table 6, and Additional data file 13). In other instances, for example the Hsp70-related genes (ABo62116, AF210640, AFoo6007) or the sequestosome1 gene (AW343560), the mixture induced a strong increase in transcript levels, whereas significant gene responses (more than twofold, $p_{\text {adj }}<0.025$ ) were not induced by administration of the individual compounds (see Figure 6d, arrowheads, Table 6, Additional data file 13). These genes can, however, be induced by higher concentrations of the individual compounds (see Figures 3, 6a,b and Additional data files 10, 11), suggesting that the observed synergy is the result of a lowered response threshold. Curiously, we also noted loss of gene responses on exposure to the compound mixture (see Figure 6d), suggesting suppressive effects of the combination. For example, the transcript levels of glutathione- $S$-transferase omega 1 (AW019036) are significantly altered by exposure to $\mathrm{PbCl}_{2}$, but not by the mixture (see Table 3 and Additional data file 13). In a few instances we observed opposing effects, such as in the case of suppressor of cytokine signalling 3 (BI878700), which was 4.9-fold downregulated by As and 2.6-fold upregulated by the mixture (see Additional data file 13). Taken together, these results show potentiated, additive, and nonadditive effects of the mixture in comparison to the individual compounds.

\section{Discussion}

We have shown that a diverse set of 11 chemicals induces highly specific gene responses in the zebrafish embryo. Moreover, synergy effects and responses to low-dose exposure 


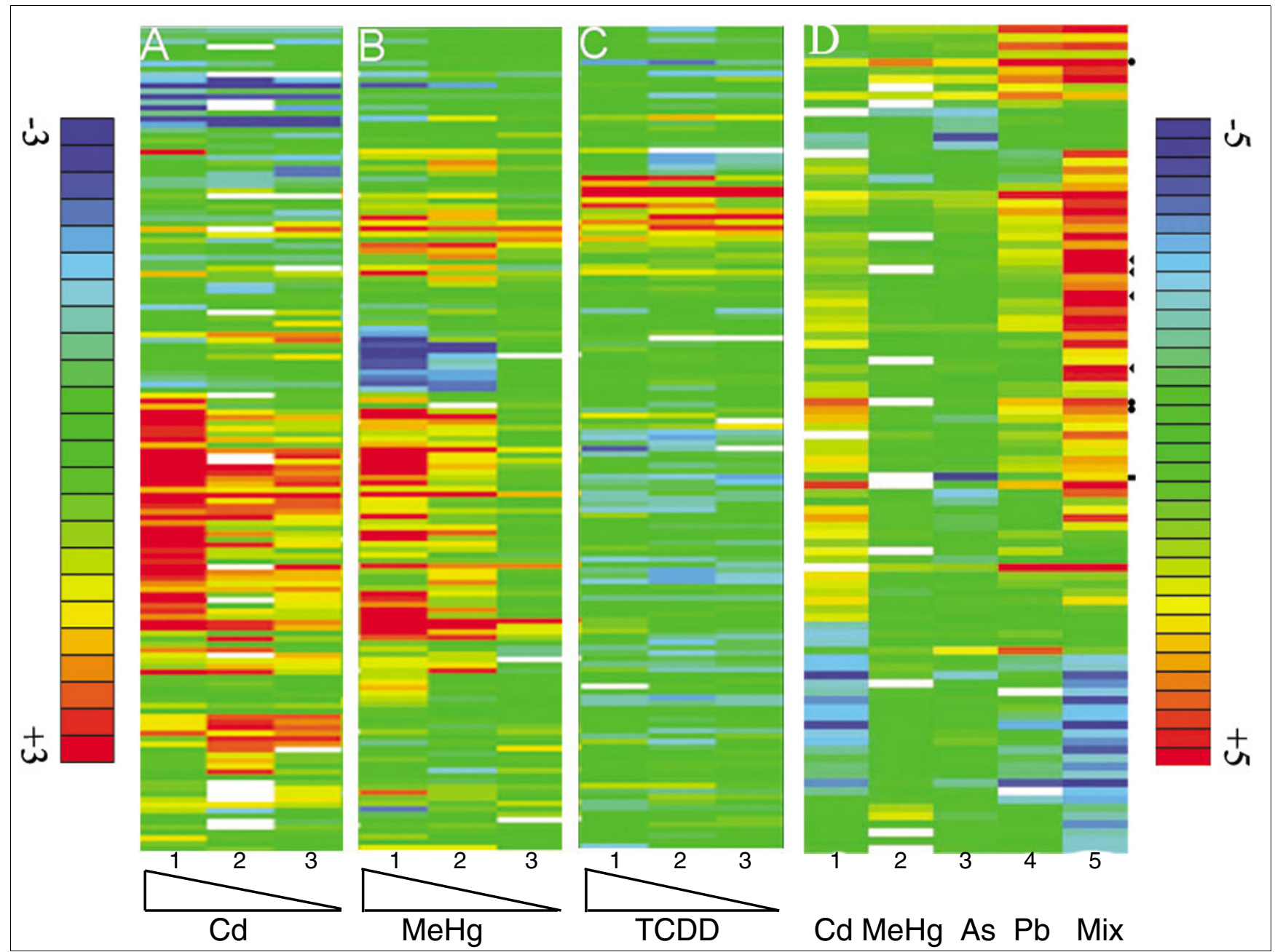

\section{Figure 6}

The concentration dependence of toxicogenomic responses and the synergistic effects of low doses. (a-c) Embryos were exposed to decreasing concentrations of Cd (a, lane I, 5 mg/l: lane 2, $2.5 \mathrm{mg} / \mathrm{l}$; lane 3, $0.5 \mathrm{mg} / \mathrm{l})$, or MeHg (b, lane I, $60 \mu \mathrm{g} / \mathrm{l}$; lane 2, $30 \mu \mathrm{g} / \mathrm{l}$; lane 3, $6 \mu \mathrm{g} / \mathrm{l})$ or TCDD (c, lane I, 500 $\mathrm{ng} / \mathrm{l}$; lane 2, $250 \mathrm{ng} / \mathrm{l}$; lane 3, $50 \mathrm{ng} / \mathrm{ll}$ ). The low concentrations elicit significant changes in gene expression. (d) Embryos were exposed either to $50 \mu \mathrm{g} / \mathrm{l} \mathrm{Cd}$ (lane I) or $6 \mu \mathrm{g} / \mathrm{I} \mathrm{MeHg}$ (lane 2) or $7.9 \mathrm{mg} / \mathrm{l} \mathrm{As} \mathrm{(lane} \mathrm{3)} \mathrm{or} 280 \mu \mathrm{g} / \mathrm{l} \mathrm{Pb}$ (lane 4) alone, or to a mixture (Mix, lane 5$)$ of Cd $(50 \mu g / l), \mathrm{Pb}(280 \mu g / l), M e H g(6$ $\mu \mathrm{g} / \mathrm{l})$ and As $(7.9 \mathrm{mg} / \mathrm{l})$. The mixture shows a strongly increased response with respect to the degree of changes of expression of individual genes (dark red and dark blue bars). Arrowheads point to examples of synergistic responses whereas the dots highlight genes whose response seems to be additive. The square indicates a gene that was downregulated by As and slightly upregulated by the mixture. All exposures were performed between 96 and I20 hpf. The color key for fold changes in gene expression in (a-c) is indicated on the left and ranges from threefold upregulated (red) to threefold downregulated (blue). The color key for (d) is on the right and ranges from fivefold upregulated (red) to fivefold downregulated (blue). White bars indicate missing data. Only genes were listed whose mRNA levels changed by at least twofold $\left(p_{\mathrm{adj}}<0.025\right)$ in at least one of the treatments. The data represent the average over all biological and technical repeats (see Table I).

were detectable in the genome-wide transcriptional response. Our work provides proof of principle that the zebrafish embryo can serve as a specific and highly sensitive whole-animal model to monitor the toxicogenomic impact of chemicals.

Although vertebrate cell lines and other in vitro test methods have great merits in assessing toxicological effects of drugs and pollutants, they cannot replace whole animal test systems entirely. The classical animal models such as mice, rats and rabbits are expensive and attract concerns from animal-rights groups. Zebrafish embryos before the feeding stage offer a cheap and ethically acceptable vertebrate model that will not only be useful in the toxicological assessment of the tens of thousands of compounds to be tested under the REACH program but can also help to evaluate the developmental toxicity of novel compounds at an early stage of drug development.

The requirement for adequate animal models for assessing developmental toxicology is further underscored by the remarkable stage dependence of the observed toxicogenomic profiles. These differences in gene responses are likely to be a reflection of the dynamics of cell differentiation and morphogenesis, which will be impossible to model in all their aspects in cell culture and other in vitro systems. The differences in 
Table 6

\begin{tabular}{|c|c|c|c|}
\hline Toxicants & Stage & Concentration & Number of regulated genes \\
\hline \multirow[t]{3}{*}{$4 C A$} & $120 \mathrm{hpf}$ & $50 \mathrm{mg} / \mathrm{l}$ & 201 \\
\hline & & $25 \mathrm{mg} / \mathrm{l}$ & 2 \\
\hline & & $5 \mathrm{mg} / \mathrm{l}$ & 0 \\
\hline \multirow[t]{3}{*}{$\mathrm{Cd}$} & $120 \mathrm{hpf}$ & $5 \mathrm{mg} / \mathrm{l}$ & 475 \\
\hline & & $2.5 \mathrm{mg} / \mathrm{l}$ & 102 \\
\hline & & $0.5 \mathrm{mg} / \mathrm{l}$ & 57 \\
\hline \multirow[t]{3}{*}{ DDT } & $120 \mathrm{hpf}$ & $15 \mathrm{mg} / \mathrm{l}$ & 25 \\
\hline & & $1.5 \mathrm{mg} / \mathrm{l}$ & 0 \\
\hline & & $0.15 \mathrm{mg} / \mathrm{l}$ & 0 \\
\hline \multirow[t]{3}{*}{ TCDD } & $120 \mathrm{hpf}$ & $500 \mathrm{ng} / \mathrm{l}$ & 34 \\
\hline & & $250 \mathrm{ng} / \mathrm{l}$ & 34 \\
\hline & & $50 \mathrm{ng} / \mathrm{l}$ & 4 \\
\hline \multirow[t]{3}{*}{ VA } & $120 \mathrm{hpf}$ & $50 \mathrm{mg} / \mathrm{l}$ & 335 \\
\hline & & $25 \mathrm{mg} / \mathrm{l}$ & 1 \\
\hline & & $5 \mathrm{mg} / \mathrm{l}$ & 4 \\
\hline \multirow[t]{3}{*}{$\mathrm{MeHg}$} & $120 \mathrm{hpf}$ & $60 \mu g / 1$ & 417 \\
\hline & & $30 \mu g / l$ & 20 \\
\hline & & $6 \mu g / l$ & 9 \\
\hline
\end{tabular}

The fold change was equal to or greater than 1.5 and $p_{\text {adj }}<0.025$. Note that for reasons of increased sensitivity we used a lower fold-change cutoff in this experiment compared with that in Figure $2 b$, which explains the higher number of regulated genes in this set of experiments.

gene responses were particularly striking at early stages, presumably reflecting the fact that many organs exist only as rudiments at these times and have not fully acquired their physiological function. It is also possible that the interembryonic variability of the gene responses is higher at this stage, blurring the gene-expression changes in the pooled cDNA.

Previous work showed that the sensitivity of the zebrafish embryo to toxicants equals that of the commonly used tests on adult freshwater fish, allowing a reliable prediction of the toxic potential of chemicals [10,11]. The embryonic DarT assay $[10,11]$ uses an exposure paradigm from cleavage stages to $48 \mathrm{hpf}$ and relies on a set of morphological endpoints and lethality. Morphological readouts provide little discrimination between the effects of different compounds, especially in the case of environmental toxicants with a broad spectrum of toxic effects on the embryo. In marked contrast to the morphological endpoints, we found highly specific patterns of transcriptional changes, resulting in barcode-like patterns of gene responses. With one exception, we were able to predict the chemical unequivocally by its pattern of induced geneexpression changes. In most cases, these patterns are related, forming distinct subgroups of profiles, but are still sufficiently different from one another to discriminate the individual compounds.

Strikingly, a general response to oxidative stress or protein damage does not seem to exist in the zebrafish embryo. A number of the chemicals (see Table 3 ) induced genes involved in the cellular systems that combat the effects of oxidative stress [32]. However, the induced oxidative-stress genes differed between chemicals, suggesting toxicant-specific effects (see Table 3). A similar observation was made with respect to chaperones (see Table 4). The tissue-specific expression of these genes as well as restricted tissue effects of the toxicant may be important in this context. For example, the expression of the thioredoxin-like gene is restricted to a small number of neurons in the brain. In in situ hybridization experiments, strong elevation of thioredoxin-like mRNA levels in response to $\mathrm{Cd}$ and $\mathrm{MeHg}$ was also noticed in the hair cells of the lateral line as well as in the brain. The differences in the type of induced defense genes and their tissue-restricted expression suggest tissue-specific effects of the different toxicants.

Another Gene Ontology (GO) group that is differentially regulated by exposure to a number of toxicants is represented by members of the solute carrier (SLC) family (Table 5). These transmembrane proteins have key roles in the transport of small molecules including neurotransmitters across vesicular and plasma membranes [33]. It is tempting to speculate that the specific downregulation of the GABA transporter SCL6 member 1 by VA (see Table 5) may be related to the therapeutic effect of VA as a suppressor of epileptic seizures.

The concentrations that elicited toxicogenomic responses are in the range of pollutant levels prevailing in the environment. We did not, however, exclude the possibility that compounds 
accumulate in the embryo, resulting in higher intra-embryonic concentrations than in the environment. Toxicogenomic responses were triggered by TCDD, Cd, DDT, and VA at concentrations that did not cause changes in morphology. Thus the genomic response appears to be more sensitive to toxic insult than is morphogenesis. A crucial question is whether the gene responses that are not obviously correlated with pathological alterations are indeed deleterious to the animal. For example, TCDD was shown to induce a battery of genes in the mouse paw (including homologs of genes we scored in our study) without obvious teratological consequences to paw development [34]. Future work will need to address whether the low-level effects on gene expression could be correlated with, and hence used to predict, chronic effects of long-term exposure.

The lowest concentration of $\mathrm{MeHg}(6 \mu \mathrm{g} / \mathrm{l})$ triggered significant changes in gene expression. In addition, we also noted teratological effects on movement and tail development at these concentrations (L.Y. and J.R.K., unpublished work), indicating that low concentrations of $\mathrm{MeHg}$ are acutely toxic in the zebrafish embryo. Disturbingly, blood serum levels of $\mathrm{MeHg}$ in humans can be in the same concentration range [35]. The zebrafish embryo may be much more susceptible to $\mathrm{MeHg}$, but defining blood serum levels that are regarded as safe in humans is an active area of research.

Application of a mixture of $\mathrm{MeHg}, \mathrm{Cd}, \mathrm{As}$, and $\mathrm{Pb}$ at low concentrations resulted in synergistic effects with more than additive numbers of genes affected and also novel patterns of gene-expression changes. Clearly, some of the genes affected by exposure to the mixture would be induced or repressed by higher concentrations of the individual chemicals. Examples are the thioredoxin and Hsp70 genes. Thus, it appears that the threshold at which induction occurs is lowered. This agrees with previous studies of mixture effects that support the notion of 'concentration addition', in which a component of the mixture can be replaced by an equipotent concentration of another compound [31]. The patterns of gene-expression changes induced individually by the four chemicals differed, however, suggesting that other effects have to be taken into account that cannot be explained by an additive mechanism of action.

Expression levels of genes, and presumably also responses to environmental toxicants, can vary dramatically between individuals. In a systematic study of variation in gene expression in natural populations of fish of the genus Fundulus, significant differences in gene expression were noted in $18 \%$ of the 907 genes analyzed [36]. In this respect, zebrafish embryos have a big advantage over mammalian systems as one can easily obtain large numbers of embryos and can thus average the individual gene responses by using pooled cDNA prepared from many embryos. In the cases where we confirmed the gene responses by in situ hybridization, we found that most individuals showed the expected upregulation, suggest- ing that many of the observed responses have a high penetrance.

While the complete development outside of the mother and the transparency of the zebrafish embryos are certainly important advantages for observation, the small size of the embryos limits the possibility of dissecting particular organs for toxicogenomic analysis. To overcome these limitations, one can use transgenic animals expressing green fluorescent protein and fluorescence-activated cell sorting to enrich for particular cell types [37]. Moreover, even whole-embryo exposure protocols as we used here permit detection of highly tissue-restricted gene responses such as those seen, for example, in the lateral line, which comprises only a very small fraction of the whole embryo.

\section{Conclusion}

The induction of the Hsp7o gene was previously shown to be a sensitive biomarker in zebrafish for exposure to $\mathrm{Cd}$ and other heavy metals [38]. The work presented here adds a long list of other highly sensitive biomarkers to be developed as transgenic biosensors. We believe that the zebrafish could become a key model for molecular developmental toxicology. Functional studies of TCDD toxicity in the zebrafish embryo well illustrate this (reviewed in [39]). Forward genetics [4043], targeting-induced local lesions in genomes (TILLING) [40], morpholino knockdown [44], transgenesis [38,45] and in situ expression studies $[46,47]$ at cellular resolution represent a powerful technical repertoire for dissecting toxicological pathways. Moreover, a large number of developmental mutants have been isolated, some of which may serve as direct targets for drugs and toxicants $[48,49]$. We believe that the work on the toxicogenomics of zebrafish embryos reported here is a fundamental contribution to the use of the zebrafish embryo as a model system for molecular developmental toxicology.

\section{Materials and methods}

\section{Chemicals and embryo treatment}

AA (acrylamide; $\mathrm{CH}_{2}=\mathrm{CHCONH}_{2}$ ), PCB (Aroclor 1254), As (arsenic (III) oxide; $\mathrm{As}_{2} \mathrm{O}_{3}$ ), tBHQ (tert-butylhydroquinone; $\left.\left(\mathrm{CH}_{3}\right)_{3} \mathrm{CC}_{6} \mathrm{H}_{3}-1,4-(\mathrm{OH})_{2}\right)$, $\mathrm{Cd}$ (cadmium chloride; $\mathrm{CdCl}_{2} 2 \mathrm{H}_{2} \mathrm{O}$ ), $4 \mathrm{CA}$ (4-chloroaniline; $\mathrm{ClC}_{6} \mathrm{H}_{4} \mathrm{NH}_{2}$ ), DDT (1,1bis-(4-chlorphenyl)-2,2,2-trichlorethane; $\left.\mathrm{ClC}_{6} \mathrm{H}_{4}\right)_{2} \mathrm{CHCCl}_{3}$ ), $\mathrm{Pb}$ (lead (II) chloride; $\mathrm{PbCl}_{2}$ ), $\mathrm{MeHg}$ (methylmercury chloride; $\mathrm{CH}_{3} \mathrm{ClHg}$ ), $\mathrm{TCDD}$ (2,3,7,8-tetrachlorodibenzo-p-dioxin) and VA (valproic acid; $\left.\mathrm{CH}_{3}\left(\mathrm{CH}_{2}\right)_{4} \mathrm{CO}_{2} \mathrm{H}\right)$ were purchased from Sigma-Aldrich (St Louis, MO).

Wild-type zebrafish strains $\mathrm{AB}, \mathrm{ABO}$ and Tübingen were kept and bred as described [50]. Embryos were grown in embryo medium (6o $\mu \mathrm{g} / \mathrm{ml}$ Instant Ocean, Red Sea, Houston, TX). Different numbers of embryos were exposed to the chemicals: 4-24 hpf (6oo embryos), 24-48 hpf (400 embryos) and 96- 
120 hpf (200 embryos). Vehicle controls used were embryo medium alone (for $\mathrm{Cd}, \mathrm{Hg}, \mathrm{Pb}$, As, VA, AA treatments) or $0.2 \%$ ethanol in embryo medium (for tBHQ, $4 \mathrm{CA}, \mathrm{PCB}$, DDT treatments) or $0.025 \% \mathrm{DMSO}, 1.4 \mathrm{mg} / \mathrm{l}$ toluene in embryo medium (500 ng/l TCDD) or 0.0075\% DMSO, $420 \mu \mathrm{g} / \mathrm{l}$ toluene (150 ng/l TCDD) or 0.0025\% DMSO, $140 \mu \mathrm{g} / \mathrm{l}$ toluene (50 ng/l TCDD). Toxicant concentrations were adjusted in such a way that embryo death was minimal. The few dead embryos were discarded before preparation of RNA. None of the vehicle controls had an apparent toxic effect on the embryos by itself. As the toluene-related chemical benzene can synergize with TCDD [51] we cannot completely exclude a synergistic effect between TCDD and toluene at the $1.4 \mathrm{mg} / \mathrm{l}$ toluene concentration.

\section{Microarray analysis}

A total of 16,399 gene-specific 65mers designed by Compugen (Jamesburg, NY) and produced by Sigma-Genosys (The Woodlands. TX) were purchased and the probes (40 mM) were spotted in duplicate in two separate subarrays using a Gene Machines Omnigrid 100 (San Carlos, CA) and TeleChem SMP3 pins (Sunnyvale, CA) on CodeLink activated slides (GE Healthcare, Chalfont St Giles, UK). Upon evaluation it turned out, however, that plates 29 to 43 had faulty amine linkers, impairing the retention of the oligonucleotides on the coat-link slides. As the companies were unable to replace the defective oligonucleotides, we used the reduced set of intact oligonucleotides (384-well plates 1 to 28 ).

Total RNA was isolated from toxicant- and vehicle-treated embryos in every experiment in parallel using the Nucleospin RNA L Kit (Macherey-Nagel, Düren, Germany) and mRNA was extracted with the Ambion Purist Kit (Austin, TX). Labelled cDNA was synthesized from 1-2 $\mu \mathrm{g}$ mRNA using the Amersham direct cDNA labeling kit (Amersham Europe, Freiburg, Germany). Upon removal of unincorporated nucleotides over Microcon 30 spin columns (Millipore, Bedford, MA), the concentrated probes were hybridized to the microarray in $1 \times$ DIG Easy-Hyb buffer (Hoffmann-La Roche, Basel, Switzerland) overnight at $42^{\circ} \mathrm{C}$. Coverslips were removed from the slides by flushing with $4 \times$ SSC and slides were washed in prewarmed wash buffer 1 ( $2 \times \mathrm{SSC}, 0.1 \% \mathrm{SDS})$ for $5 \mathrm{~min}$ at $42^{\circ} \mathrm{C}$, then in buffer $2(0.1 \times \mathrm{SSC}, 0.1 \% \mathrm{SDS})$ for 10 $\mathrm{min}$ at room temperature, and finally in $0.1 \times$ SSC four times for $1 \mathrm{~min}$ at room temperature. The slides were briefly dipped into $0.01 \times \mathrm{SSC}$ at room temperature before centrifugation for $7 \mathrm{~min}$ at $800 \mathrm{rpm}$ in an Eppendorf $5810 \mathrm{R}$ centrifuge.

Arrays were scanned using the Axon model $4000 B$ dual-laser scanner and the corresponding GenePix 6 software (Molecular Devices, Union City, CA). Both channels (532 nm for Cy3 and $635 \mathrm{~nm}$ for Cy5) were scanned in parallel and stored as 16-bit TIFF files. Each array was scanned three times (low, medium, and high scan) with different signal-amplification factors (voltage settings of the photomultiplier tubes), but with the same laser power. The channels for Cy3 and Cy5 were balanced in each scan for approximately the same intensity range. For the low scan no spot was saturated; in the high scan the signal amplification for Cy5 was set to approximately $80 \%$ of maximum and $\mathrm{Cy} 3$ amplification was adjusted to this. The settings used in the medium scan lie between the low and the high scan. The absolute intensity values span the range from o to 65536. The scans were performed with a resolution of $10 \mu \mathrm{m}$. From each spot with a mean diameter of $100 \mu \mathrm{m}$, 70-80 pixels were recorded. Individual local background areas around the spots were defined, which comprised approximately 400 pixels. For each channel, the spot signals were calculated as the median intensity of all foreground pixels minus the median intensity of all background pixels.

All microarray data from this study have been deposited in NCBI's Gene Expression Omnibus under the accession number GPL4603.

\section{Data preprocessing, quality control, transformation, and normalization}

Raw data was derived from the result files generated by the GenePix 6 suite and analyzed with the R software [52]. Preprocessing of data comprises mapping of scans, quality control, transformation, and normalization steps. Signal intensities from low, medium, and high scans are mapped onto the same scale by an affine transformation. Transformation parameters are estimated based on a least-squares optimization. Averaging the transformed intensities gives the consensus signals, which are independent of the voltage settings of the photomultiplier tube.

Quality control was performed on a spot and array level. Spots ideally have a diameter of $100 \mu \mathrm{m}$. Diameters less than $70 \mu \mathrm{m}$ and greater than $140 \mu \mathrm{m}$ are indicative of scratches and printing problems and the corresponding data was discarded. In addition, inconsistent spots with a coefficient of variance of pixels bigger than 0.7 , and weak spots with a foreground signal less than $175 \%$ of the background signal were removed from further analyses. Strong but unreliable signals with at least $20 \%$ of pixels in saturation were discarded. Quality control on array level determined the overall quality of each single chip. Therefore, results from different arrays were compared with each other on the basis of correlation parameters, scatterplots and chi-plots for all combinations of arrays for a particular treatment [53,54]. Raw intensities were transformed with the natural logarithm. A locally weighted regression smoother (LOESS) was applied to correct intensitydependent signal patterns [55]. The regression is a first-order polynomial that takes into account the subset of $25 \%$ of spots that yield a signal with similar intensities. Variance stabilization for weakly expressing genes was not performed as such effects were not apparent. All chips hybridized for a particular treatment were scaled to a common median absolute deviation from median (MAD) of the logarithmic fold change (M value) [56]. Statistical analysis was based on the assumption that the majority of genes are not changed in their expression 
and that the overall up- and downregulations compensate each other in sum.

Each individual gene was tested for difference in expression under toxic conditions with a $t$-test where an adjusted $p$ value $\left(p_{\text {adj }}\right)$ of less than 0.025 indicated significant differential expression. Statistical requirements of normal distribution and homoscedasticity are tenable. A robust variance estimation was derived by balancing gene-specific and pooled variance [57]. The number of false positives due to multiple testing was reduced by adjusting the resulting $p$ values by controlling the Benjamini-Hochberg false discovery rate [27].

Multivariate analysis was based on a subset of genes of interest. Genes that remain unchanged under all conditions were ignored. Marker genes that are significantly changed by exposure to a particular toxicant were taken into account. In addition, the selected subset included genes that showed a global response across many chemicals. The selected subset included: the top 20 up- or downregulated genes based on fold change (minimum fold change > 2); the top seven genes with the highest correlation among at least two toxicants (minimum correlation > 0.7); the top 100 genes with the highest MAD across all treatments; and the marker genes that are regulated at least threefold for just one treatment.

Most multivariate approaches require a complete dataset without missing values. Under the condition that more than $80 \%$ of the data for a particular gene is available, missing data for gene $g$ are imputed by a k-nearest-neighbor algorithm [58]. Missing values are estimated as weighted average of the values for the $k$ genes with the closest Euclidean distance to gene $g$.

The logarithmic fold changes (M values) of genes under toxic conditions are subjected to PCA and hierarchical clustering. The principal components of experimental data across all experiments were derived by SVD [59]. Gene-expression profiles summarize clustering information for toxicants and genes. Dissimilarity between toxicants is determined as Euclidean distance of their $\mathrm{M}$ values. In contrast, proximity between two genes is derived as the arc cosine transformed Pearson correlation coefficient [6o].

GO analysis of toxicant-affected genes was carried out by extracting the human homologs from the Zebrafish Chip Annotation Database [61]. The GO trees and categories were established with the web-based GoTreeMachine [62]. The number of genes with significant alterations in expression levels in response to TCDD, DDT, and AA were too few to be analyzed by GoTreeMachine.

\section{Expression analysis}

In situ hybridization and RT-PCR were carried out using standard procedures $[46,63]$. The sequences of the primers used in RT-PCR are listed in Additional data file 14. Embryos and RNA samples were derived from independent toxicant exposures. Cell death was monitored by acridine orange staining and examination by fluorescence microscopy [64].

\section{Additional data files}

Additional data is available online with this paper. Additional data file 1 summarizes the preliminary data evaluating the effectiveness of toxin treatment. Additional data file 2 contains a GO tree for arsenic oxide. Additional data file 3 contains a GO tree for $4 \mathrm{CA}$. Additional data file 4 contains a GO tree for cadmium chloride. Additional data file 5 contains a GO tree for methylmercury. Additional data file 6 contains a GO tree for lead chloride. Additional data file 7 contains a GO tree for PCB. Additional data file 8 contains a GO tree for tBHQ. Additional data file 9 contains a GO tree for VA. Additional data file 10 summarizes gene responses of embryos exposed to different concentrations of $\mathrm{Cd}$. Additional data file 11 summarizes gene responses of embryos exposed to different concentrations of $\mathrm{MeHg}$. Additional data file 12 summarizes gene responses of embryos exposed to different concentrations of TCDD. Additional data file 13 summarizes gene responses of embryos exposed to $50 \mu \mathrm{g} / 1 \mathrm{CdCl}_{2}(\mathrm{Cd})$ or 6 $\mu \mathrm{g} / \mathrm{l} \mathrm{MeHg}\left(\mathrm{MeHg}\right.$ ) or $7.9 \mathrm{mg} / \mathrm{l} \mathrm{As}_{2} \mathrm{O}_{3}$ (As) or $280 \mu \mathrm{g} / \mathrm{l} \mathrm{PbCl}_{2}$ $(\mathrm{Pb})$ alone or to a mixture (Mix). Additional data file 14 is a list of primers used in the RT-PCR experiments shown in Figure 4 .

\section{Authors' contributions}

L.Y. and U.S. conceived the work and designed the experiments. U.S. supervised the project and wrote the manuscript. L.Y. performed all of the experimental work. J.R.K. optimized some of the concentrations of the toxicants. C.Z. and J.J performed statistical analysis of the microarray data. M.B. and M.P. provided technical assistance in microarray printing. F.M. gave technical advice at an early stage of the project. J.L. performed the gene ontological analysis.

\section{Acknowledgements}

We thank M. Rastegar and S. Rastegar for their help in lab organization, and J. Katzenberger, M. Bonnaus and N. Gretz for technical assistance. This work was supported through the Additional Funding Scheme of the Helmholtz-Gemeinschaft.

\section{References}

I. Andreasen EA, Mathew LK, Tanguay RL: Regenerative growth is impacted by TCDD: gene expression analysis reveals extracellular matrix modulation. Toxicol Sci 2006, 92:254-269.

2. Yoon CY, Park M, Kim BH, Park JY, Park MS, Jeong YK, Kwon H, Jung $H K$, Kang H, Lee YS, et al:: Gene expression profile by $2,3,7,8$ tetrachlorodibenzo-p-dioxin in the liver of wild-type $(A h R+I$ + ) and aryl hydrocarbon receptor-deficient (AhR-l-) mice. J Vet Med Sci 2006, 68:663-668.

3. Koizumi S, Yamada H: DNA microarray analysis of altered gene expression in cadmium-exposed human cells. J Occup Health 2003, 45:33I-334. 
4. Hood RD: Handbook of Developmental Toxicology Boca Raton, FL: CRC Press; 1997.

5. Combes R, Dandrea J, Balls M: A critical assessment of the European Commission's proposals for the risk assessment and registration of chemical substances in the European Union. Altern Lab Anim 2006, 34(Suppl I):29-40.

6. Grindon C, Combes R: Introduction to the EU REACH legislation. Altern Lab Anim 2006, 34(Suppl I):5-10.

7. Suter $L$, Babiss $L E$, Wheeldon EB: Toxicogenomics in predictive toxicology in drug development. Chem Biol 2004, I I:I6I-I7I.

8. Kimmel CB, Ballard WW, Kimmel SR, Ullmann B, Schilling TF: Stages of embryonic development of the zebrafish. Dev Dyn 1995, 203:253-310.

9. Zon LI, Peterson RT: In vivo drug discovery in the zebrafish. Nat Rev Drug Discov 2005, 4:35-44.

10. Nagel R: DarT: The embryo test with the Zebrafish Danio rerio - a general model in ecotoxicology and toxicology. Altex 2002, I 9(Suppl I):38-48.

II. Braunbeck T, Boettcher M, Hollert H, Kosmehl T, Lammer E, Leist E, Rudolf $M$, Seitz N: Towards an alternative for the acute fish LC(50) test in chemical assessment: the fish embryo toxicity test goes multi-species - an update. Altex 2005, 22:87-102.

12. Alestrom P, Holter JL, Nourizadeh-Lillabadi R: Zebrafish in functional genomics and aquatic biomedicine. Trends Biotechnol 2006, 24: I5-2I.

13. Langheinrich U: Zebrafish: a new model on the pharmaceutical catwalk. BioEssays 2003, 25:904-912.

14. Parng C: In vivo zebrafish assays for toxicity testing. Curr Opin Drug Discov Dev 2005, 8:100- 106.

15. Mathavan S, Lee SG, Mak A, Miller LD, Murthy KR, Govindarajan KR, Tong Y, Wu YL, Lam SH, Yang H, et al.: Transcriptome analysis of zebrafish embryogenesis using microarrays. PLoS Genet 2005, I:260-276.

16. Lam SH, Wu YL, Vega VB, Miller LD, Spitsbergen J, Tong Y, Zhan H, Govindarajan KR, Lee S, Mathavan S, et al:: Conservation of gene expression signatures between zebrafish and human liver tumors and tumor progression. Nat Biotechnol 2006, 24:73-75.

17. Linney E, Dobbs-McAuliffe B, Sajadi H, Malek RL: Microarray gene expression profiling during the segmentation phase of zebrafish development. Comp Biochem Physiol C Toxicol Pharmacol 2004, 138:35I-362.

18. Lien CL, Schebesta M, Makino S, Weber G], Keating MT: Gene expression analysis of zebrafish heart regeneration. PLOS Biol 2006, 4:e260.

19. Xu J, Srinivas BP, Tay SY, Mak A, Yu X, Lee SG, Yang H, Govindarajan $K R$, Leong B, Bourque G, et al:: Genomewide expression profiling in the zebrafish embryo identifies target genes regulated by Hedgehog signaling during vertebrate development. Genetics 2006, 174:735-752.

20. Meijer AH, Verbeek FJ, Salas-Vidal E, Corredor-Adamez M, Bussman J, van der Sar AM, Otto GW, Geisler R, Spaink HP: Transcriptome profiling of adult zebrafish at the late stage of chronic tuberculosis due to Mycobacterium marinum infection. Mol Immunol 2005, 42: I I 85-1203.

21. Voelker D, Vess C, Tillmann M, Nagel R, Otto GW, Geisler R, Schirmer K, Scholz S: Differential gene expression as a toxicantsensitive endpoint in zebrafish embryos and larvae. Aquat Toxicol 2007, $81: 355-364$.

22. Lam SH, Winata CL, Tong Y, Korzh S, Lim WS, Korzh V, Spitsbergen J, Mathavan S, Miller LD, Liu ET, et al:: Transcriptome kinetics of arsenic-induced adaptive response in zebrafish liver. Physiol Genomics 2006, 27:35I-36I.

23. Andreasen EA, Mathew LK, Lohr CV, Hasson R, Tanguay RL: Aryl hydrocarbon receptor activation impairs extracellular matrix remodeling during zebra fish fin regeneration. Toxicol Sci 2007, 95:215-226.

24. EPA: welcome to ECOTOX [http://cfpub.epa.gov/ecotox/ quick_query.htm]

25. Nau $\bar{H}$, Hauck RS, Ehlers $K$ : Valproic acid-induced neural tube defects in mouse and human: aspects of chirality, alternative drug development, pharmacokinetics and possible mechanisms. Pharmacol Toxicol 1991, 69:310-321.

26. Wiltse J: Mode of action: inhibition of histone deacetylase, altering WNT-dependent gene expression, and regulation of beta-catenin--developmental effects of valproic acid. Crit Rev Toxicol 2005, 35:727-738.

27. Benjamini Y, Hochberg Y: Controlling the false discovery rate: $A$ practical approach to multiple testing. J $R$ Stat Soc 1995,
57:289-300.

28. Linbo TL, Stehr CM, Incardona JP, Scholz NL: Dissolved copper triggers cell death in the peripheral mechanosensory system of larval fish. Environ Toxicol Chem 2006, 25:597-603.

29. Santos F, MacDonald G, Rubel EW, Raible DW: Lateral line hair cell maturation is a determinant of aminoglycoside susceptibility in zebrafish (Danio rerio). Hear Res 2006, 213:25-33.

30. Chen WY, John JA, Lin CH, Chang CY: Expression pattern of metallothionein, MTF-I nuclear translocation, and its DNAbinding activity in zebrafish (Danio rerio) induced by zinc and cadmium. Environ Toxicol Chem 2007, 26: I I0-1 I7.

3I. Escher BI, Hermens JL: Modes of action in ecotoxicology: their role in body burdens, species sensitivity, QSARs, and mixture effects. Environ Sci Technol 2002, 36:4201-42I7.

32. Winyard PG, Moody CJ, Jacob C: Oxidative activation of antioxidant defence. Trends Biochem Sci 2005, 30:453-46I.

33. Gether U, Andersen PH, Larsson OM, Schousboe A: Neurotransmitter transporters: molecular function of important drug targets. Trends Pharmacol Sci 2006, 27:375-383.

34. Bemis JC, Alejandro NF, Nazarenko DA, Brooks Al, Baggs RB, Gasiewicz TA: TCDD-induced alterations in gene expression profiles of the developing mouse paw do not influence morphological differentiation of this potential target tissue. Toxicol Sci 2007, 95:240-248.

35. Centers for Disease Control and Prevention [http:// www.cdc.gov/exposurereport/pdf/factsheet_mercury.pdf]

36. Oleksiak MF, Churchill GA, Crawford DL: Variation in gene expression within and among natural populations. Nat Genet 2002, 32:261-266.

37. Dickmeis T, Plessy C, Rastegar S, Aanstad P, Herwig R, Chalmel F, Fischer N, Strahle U: Expression profiling and comparative genomics identify a conserved regulatory region controlling midline expression in the zebrafish embryo. Genome Res 2004, 14:228-238.

38. Blechinger SR, Warren JT Jr, Kuwada JY, Krone PH: Developmental toxicology of cadmium in living embryos of a stable transgenic zebrafish line. Environ Health Perspec 2002, I I 0: 104 I- 1046.

39. Carney SA, Prasch AL, Heideman W, Peterson RE: Understanding dioxin developmental toxicity using the zebrafish model. Birth Defects Res A Clin Mol Teratol 2006, 76:7-18.

40. Sood R, English MA, Jones M, Mullikin J, Wang DM, Anderson M, Wu D, Chandrasekharappa SC, Yu J, Zhang J, et al.: Methods for reverse genetic screening in zebrafish by resequencing and TILLING. Methods 2006, 39:220-227.

41. Driever W, Solnica-Krezel L, Schier AF, Neuhauss SC, Malicki J, Stemple DL, Stainier DY, Zwartkruis F, Abdelilah S, Rangini Z, et al:: A genetic screen for mutations affecting embryogenesis in zebrafish. Development 1996, I 23:37-46.

42. Mullins MC, Nüsslein-Volhard C: Mutational approaches to studying embryonic pattern formation in the zebrafish. Curr Opin Gen Dev 1993, 3:648-654

43. Amsterdam A, Hopkins $\mathrm{N}$ : Mutagenesis strategies in zebrafish for identifying genes involved in development and disease. Trends Genet 2006, 22:473-478.

44. Nasevicius A, Ekker SC: Effective targeted gene 'knockdown' in zebrafish. Nat Genet 2000, 26:216-220.

45. Hill A, Howard CV, Strahle U, Cossins A: Neurodevelopmental defects in zebrafish (Danio rerio) at environmentally relevant dioxin (TCDD) concentrations. Toxicol Sci 2003, 76:392-399.

46. Strähle U, Blader P, Adams J, Ingham PW: Non-radioactive in situ hybridization procedure for tissue sections. Trends Genet I994, 10:75-76.

47. Oxtoby $E$, Jowett $\mathrm{T}$ : Cloning of the zebrafish krox-20 gene (krx20) and its expression during hindbrain development. Nucl Acids Res 1993, 21:1087-1095.

48. Behra M, Cousin X, Bertrand C, Vonesch JL, Biellmann D, Chatonnet $A$, Strahle $U$ : Acetylcholinesterase is required for neuronal and muscular development in the zebrafish embryo. Nat Neurosci 2002, 5: III-118.

49. Behra M, Etard C, Cousin X, Strahle U: The use of zebrafish mutants to identify secondary target effects of acetylcholine esterase inhibitors. Toxicol Sci 2004, 77:325-333.

50. Westerfield M: The Zebrafish Book Eugene: University of Oregon Press; 1993.

5I. Mizell M, Romig ES: The aquatic vertebrate embryo as a sentinel for toxins: zebrafish embryo dechorionation and perivitelline space microinjection. Int J Dev Biol 1997, 42:4 I I-423.

52. The $\mathbf{R}$ Project for Statstical Computing [http://www.R-
- 
project.org]

53. Fisher NL, Switzer P: Chi-plots for assessing dependence. Biometrica 1985, 72:253-265.

54. Fisher NL, Switzer P: Graphical assessment of independence: is a picture worth 100 tests? Am Stat 200I, 55:233-239.

55. Cui X, Kerr MK, Churchill GA: Transformations for cDNA microarray data. Stat Appl Genet Mol Biol 2003, 2:Article4.

56. Yang YH, Dudoit S, Luu P, Lin DM, Peng V, Ngai J, Speed TP: Normalization for cDNA microarray data: a robust composite method addressing single and multiple slide systematic variation. Nucleic Acids Res 2002, 30:el5.

57. Baldi P, Long AD: A Bayesian framework for the analysis of microarray expression data: regularized t-test and statistical inferences of gene changes. Bioinformatics 2001, I 7:509-5I9.

58. Troyanskaya O, Cantor M, Sherlock G, Brown P, Hastie T, Tibshirani $R$, Botstein D, Altman RB: Missing value estimation methods for DNA microarrays. Bioinformatics 2001, I 7:520-525.

59. Alter O, Brown PO, Botstein D: Singular value decomposition for genome-wide expression data processing and modeling. Proc Natl Acad Sci USA 2000, 97: 10101-10106.

60. Eisen MB, Spellman PT, Brown PO, Botstein D: Cluster analysis and display of genome-wide expression patterns. Proc Natl Acad Sci USA 1998, 95:|4863-|4868.

61. Zebrafish Chip Annotation Database [http://giscompute.gis.astar.edu.sg/ govind/zebrafish]

62. Gene Ontology Tree Machine [http://bioinfo.vanderbilt.edu/ gotm]

63. Sambrook J, Russel DW: Molecular Cloning: A Laboratory Manual 3rd edition. New York: Cold Spring Harbor Press; 200I.

64. Ton C, Lin Y, Willett C: Zebrafish as a model for developmental neurotoxicity testing. Birth Defects Res (Part A) 2006, 76:553-567. 